\title{
Role of mitochondrial calcium in hypochlorite induced oxidative damage of cells
}

\author{
Vitali T. Cheshchevik ${ }^{\text {a, }}{ }^{*}$, Nina G. Krylova ${ }^{\text {b }}$, Nina G. Cheshchevik ${ }^{\text {, }}$, Elena A. Lapshina ${ }^{\text {, }}$ \\ Galina N. Semenkova ${ }^{b}$, Ilya B. Zavodnik ${ }^{c}$ \\ a Department of Biotechnology, Polessky State University, ulitsa Dnieprovskoy Flotilii, 23, 225710, Pinsk, Belarus \\ ${ }^{\mathrm{b}}$ Department of Biophysics, Belarusian State University, Prospekt Nezavisimosti 4, 220030, Minsk, Belarus \\ ${ }^{\mathrm{c}}$ Department of Biochemistry, Yanka Kupala State University of Grodno, Bulvar Leninskogo Komsomola 50, 230030, Grodno, Belarus
}

\section{A R T I C L E I N F O}

\section{Article history:}

Received 7 September 2020

Received in revised form

9 January 2021

Accepted 10 February 2021

Available online 17 February 2021

\section{Keywords:}

Mitochondria

Hypochlorite

Mitochondrial calcium

Endoplasmic reticulum (ER)

Mitochondria-associated membranes (MAMs)

\begin{abstract}
A B S T R A C $T$
Hypochlorite $(\mathrm{HOCl})$ is one of the most important mediators of inflammatory processes. Recent evidence demonstrates that changes in intracellular calcium pool play a significant role in the damaging effects of hypochlorite and other oxidants. Mitochondria are shown to be one of the intracellular targets of hypochlorite. But little is known about the mitochondrial calcium pool changes in HOCl-induced mitochondrial dysfunction. Using isolated rat liver mitochondria, we showed the oxidative damage of mitochondria (GSH oxidation and mixed protein-glutathione formation without membrane lipid peroxidation) and alterations in the mitochondrial functional parameters (decrease of respiratory activity and efficiency of oxidative phosphorylation, NADH and FADH coenzyme levels, and membrane potential) under hypochlorite action $(50-300 \mu \mathrm{M})$. Simultaneously, the mitochondrial calcium release and swelling were demonstrated. In the presence of EGTA, the damaging effects of $\mathrm{HOCl}$ were less pronounced, reflecting direct involvement of mitochondrial $\mathrm{Ca}^{2+}$ in mechanisms of oxidant-induced injury. Furthermore, exposure of HeLa cells to hypochlorite resulted in a considerable increase in cytoplasmic calcium concentrations and a decrease in mitochondrial ones. Applying specific inhibitors of calcium transfer systems, we demonstrated that mitochondria play a key role in the redistribution of cytoplasmic $\mathrm{Ca}^{2+}$ ions under hypochlorite action and act as mediators of calcium release from the endoplasmic reticulum into the cytoplasm.
\end{abstract}

(C) 2021 Elsevier B.V. and Société Française de Biochimie et Biologie Moléculaire (SFBBM). All rights reserved.

\section{Introduction}

Many diseases are associated with the development of inflammatory processes in body tissues [1,2]. Hypochlorite is considered to be one of the most important mediators of inflammation. It is produced by activated neutrophils at the inflammation sites via the

Abbreviations: CysA, cyclosporine A; Dnt, dantrolene; HOCl, hypochlorite; ER, endoplasmic reticulum; EDTA, ethylenediaminetetraacetic acid; EGTA, ethylene glycol-bis( $\beta$-aminoethyl ether)-N,N,N',N'-tetraacetic acid; FCCP, carbonyl cyanide4-trifluoromethoxy)phenylhydrazone; GSH, reduced form of glutathione; GSSP, mixed glutathione protein disulfides; RR, ruthenium red; ROS, reactive oxygen species; MPTP, membrane permeability transition pore; MDA, malonyldialdehyde; $\mathrm{IP}_{3} \mathrm{R}$, inositol 1,4,5-trisphosphate receptor; RyR, ryanodine receptor; $\mathrm{MCU}$, mitochondrial calcium uniporter.

* Corresponding author.

E-mail address: cheshchevik.v@polessu.by (V.T. Cheshchevik). myeloperoxidase-catalyzed reaction of chloride ions with hydrogen peroxide [3]. The presence of $\mathrm{HOCl}$ in the injured tissues is confirmed by accumulation of chlorinated tyrosine residues, and its concentrations can reach the values of $20-400 \mu \mathrm{M}$ during an hour $[3,4]$. As was previously shown, $\mathrm{HOCl}$ is a cytotoxic agent affecting not only microorganisms and damaged cells in the inflammation foci, but also the surrounding normal cells. In particular, chlorinated tyrosine residues have been found in many septic and periseptic tissues of human cirrhotic liver [5-7].

Hypochlorite is known to penetrate rapidly into mammalian cells, achieving intracellular targets [8]. Significant alterations in cellular physiology have already been observed within the first minutes of hypochlorite action, confirming its high cytotoxicity. In addition, hypochlorite compared to other reactive oxygen species is not a substrate for antioxidative enzymes and, at the same time, is able to interact with multiple subcellular structures [9,10]. Cell exposure to hypochlorite results in oxidation of various 
biomolecules including membrane lipids, proteins, DNA, and low weight molecules (ascorbate, nucleotides, thiol groups, thioethers) $[6,9,10]$. Moreover, $\mathrm{HOCl}$ causes protein damage due to the formation of chloramines and chlorotyrosines as well as protein thiol group oxidation [11]. Hypochlorite at low physiological concentrations (up to $400 \mu \mathrm{M}$ ) generated by neutrophils acts on specific cellular targets and induces various mechanisms of cell death depending on the cell type $[3,8,12]$.

Mitochondria are essential for cell viability, supplying the cell by energy and participating in cell signaling, particularly in apoptosis [13]. It was demonstrated that mitochondrial dysfunction plays a critical role in the pathogenesis of many diseases, and application of the mitochondria directed drugs is effective in the treatment of these diseases [13]. Mitochondria are shown to be one of the intracellular targets of hypochlorite [9,14]. Using human HepG2 cells, it was demonstrated that $\mathrm{HOCl}$ at concentrations of 15-125 $\mu \mathrm{M}$ reduced the cellular ATP level, induced the membrane permeability transition pore (MPTP) formation, mitochondrial swelling, membrane potential decrease, and release of cytochrome $C$, thereby causing the caspase 3 activation and cell death by apoptosis [9]. In human macrophages, $\mathrm{HOCl}(50-200 \mu \mathrm{M})$ brought about a rise in cytoplasmic calcium level via the plasma membrane L- and T-type calcium channels and endoplasmic reticulum RyR channels as well as cellular ATP and mitochondrial membrane potential loss, and rapid necrotic cell death [15].

Currently, a number of papers have demonstrated that changes in the intracellular calcium pool play a significant role in the damaging effects of oxidants and, in particular, hypochlorite $[8,16-21] . \mathrm{Ca}^{2+}$ is known to be involved in the regulation of many cellular signals $[8,13,22]$. Mitochondrial $\mathrm{Ca}^{2+}$ influx controls both the oxidative phosphorylation and cellular ROS generation. Whereas dysregulation of cellular $\mathrm{Ca}^{2+}$ homeostasis leads to $\mathrm{Ca}^{2+}$ elevation in the mitochondrial microenvironment, causes cell death via an impairment in ATP and mitochondrial redox homeostasis, and promotes the membrane protein thiol cross-linking, inducing mitochondrial permeability transition [23]. $\mathrm{Ca}^{2+}$ ions activated specific ATP independent proteases that resulted in damage of many cell structures including mitochondria [8]. Moreover, $\mathrm{Ca}^{2+}$ is able to activate ROS generation in mitochondria $[24,25]$. Simultaneously with the protein thiol groups oxidation under hypochlorite action, this stimulates mPTP opening [26]. Interactions between the ROS and calcium signaling can be considered as bidirectional [18]. Mitochondria can regulate intracellular $\mathrm{Ca}^{2+}$ level by forming contact sites between the mitochondria and endoplasmic reticulum (MAMs). At these sites, a rapid and significant $\mathrm{Ca}^{2+}$ release out of the endoplasmic reticulum followed by its accumulation in mitochondria occurs [27]. Although mitochondria play an important role in the regulation of cell $\mathrm{Ca}^{2+}$ homeostasis [13], little is known about hypochlorite-induced changes in mitochondrial calcium level at the inflammation sites. Similarly, the mechanisms of hypochlorite-induced mitochondrial dysfunction and cell death are still unclear.

Thus, due to the great importance of mitochondria in the cell response to hypochlorite exposure and regulation of many cellular processes, the aim of the work was to study the functional state and involvement of mitochondria in the calcium pool changes during hypochlorite-induced cell damage.

\section{Materials and methods}

\subsection{Materials}

Succinic acid disodium salt hexahydrate (succinate), L-glutamic acid sodium salt (glutamate), L-malic acid sodium salt (malate), sodium hypochlorite, sucrose, tris(hydroxymethyl)aminomethane
(Tris-HCl), 4-(2-hydroxyethyl)-1-piperazineethanesulfonic acid (Hepes), ethylene glycol-bis( $\beta$-aminoethyl ether)-N,N, $\mathrm{N}^{\prime}, \mathrm{N}^{\prime}$-tetraacetic acid (EGTA), ethylenediaminetetraacetic acid (EDTA), adenosine diphosphate sodium salt (ADP), safranin $O$, valinomycin, carbonyl cyanide-4-(trifluoromethoxy)phenylhydrazone (FCCP), 5,5'-dithiobis(2-nitrobenzoic acid), calcium chloride dehydrate, trichloroacetic acid, cyclosporine A (CysA), ruthenium red (RR), thiobarbituric acid (TBA), gentamicin, Fura-2-acetoxymethyl ester (Fura-2AM), rhod calcium indicator acetoxymethyl ester (X-Rhod1-AM), JC-1 dye and dimethyl sulfoxide were purchased from Sigma-Aldrich, St. Louis, MO, USA or Steinheim, Germany. All other reagents of analytical grade were purchased from POCh (Gliwice, Poland) and Reakhim (Moscow, Russia). All solutions were made with water purified in the Milli-Q system.

HeLa cells were grown in the Dulbecco's modified Eagle's medium with $4.5 \mathrm{~g} / \mathrm{l}$ glucose supplemented with $10 \%$ fetal bovine serum and $100 \mu \mathrm{g} / \mathrm{ml}$ gentamicin at $37{ }^{\circ} \mathrm{C}$ in a humidified atmosphere of $5 \% \mathrm{CO}_{2}$ and $95 \%$ air. When the cell monolayer reached $75-90 \%$ of confluence, the culture medium was removed, and monolayer was washed with Hepes-buffer containing $131 \mathrm{mM}$ $\mathrm{NaCl}, 5 \mathrm{mM} \mathrm{KCl}, 1.3 \mathrm{mM} \mathrm{MgSO}_{4}, 6 \mathrm{mM}$ glucose, and $20 \mathrm{mM}$ Hepes, $\mathrm{pH}$ 7.3. The cells were dissociated using $0.2 \%$ trypsin with $0.02 \%$ EDTA and resuspended by Hepes-buffer.

\subsection{Mitochondria isolation}

Mitochondria were prepared from the liver of Wistar male rats weighing 200-250 g as previously described [28]. The animals were fasted for $12 \mathrm{~h}$ until killing. The animals were killed by decapitation according to the rules of the European Convention for the Protection of Vertebrate Animals Used for Experimental and Other Scientific Purposes, and the study was approved by the Ethics Committee of the University. The liver was removed into cold $\left(0-4{ }^{\circ} \mathrm{C}\right)$ isotonic phosphate buffer $\left(150 \mathrm{mM} \mathrm{NaCl}, 10 \mathrm{mM} \mathrm{Na}_{2} \mathrm{HPO}_{4}\right.$, $\mathrm{pH}$ 7.4), dried with filter paper, weighed to provide the required quantitative yield of mitochondria and homogenized in a glassteflon Potter-Elvehjem homogenizer with the ice-cold isolation medium containing $250 \mathrm{mM}$ sucrose, $20 \mathrm{mM}$ Tris- $\mathrm{HCl}$ and $1 \mathrm{mM}$ EGTA, pH 7.2. The homogenate was centrifuged at $600 \mathrm{~g}$ for $10 \mathrm{~min}$ $\left(4{ }^{\circ} \mathrm{C}\right)$ for nuclei precipitation. Then supernatant was centrifuged at $8,500 \mathrm{~g}$ for $10 \mathrm{~min}\left(4^{\circ} \mathrm{C}\right)$. The mitochondrial pellet was washed twice with the isolation medium (with and without $1 \mathrm{mM}$ EGTA) and centrifuged at $8,500 \mathrm{~g}$ for $10 \mathrm{~min}\left(4^{\circ} \mathrm{C}\right)$ after each washing again. The mitochondrial pellet was resuspended by pipetting with the isolation medium without of EGTA to the protein concentration of $40 \mathrm{mg} / \mathrm{ml}$. All procedures were performed at $4^{\circ} \mathrm{C}$. The quality of the mitochondrial fraction was confirmed by electron microscopy (JEM-1011, Japan) at magnifications of 5,000x to $40,000 x$, and the purity of the isolated mitochondrial fraction was at least $98 \%$. The protein concentration of the mitochondrial suspension was determined using Folin-Ciocalteu reagent [29].

\subsection{Biochemical measurements}

Before biochemical measurements mitochondrial suspension was subjected to 3 cycles of freeze-thawing, mixed with $25 \%$ trichloroacetic acid, and centrifuged to precipitate of proteins at $6000 \mathrm{~g}$ for $3 \mathrm{~min}$.

The reduced mitochondrial glutathione, GSH, was determined spectrophotometrically in the mitochondria-free supernatant using 5,5'-dithiobis(2-nitrobenzoic acid) [30]. Glutathione level in mitochondria was calculated using the molar extinction coefficient $\varepsilon_{412}=13.6 \cdot 10^{3} \mathrm{M}^{-1} \mathrm{~cm}^{-1}$ and expressed as nmol GSH per mg of protein. Mixed glutathione-protein disulfides, GSSP, were measured spectrophotometrically in the mitochondrial pellet using 
5,5'-dithiobis(2-nitrobenzoic acid) and expressed as nmol GSSP per $\mathrm{mg}$ of protein [31]. Glutathione release from disulfides with protein thiol groups was performed by incubating the mitochondrial pellet with $0.5 \mathrm{M}$ sodium phosphate buffer, $\mathrm{pH} 7.4$, at $25^{\circ} \mathrm{C}$ for an hour. The content of mixed glutathione-protein disulfides was calculated in the mitochondria using the molar extinction coefficient $\varepsilon_{412}=13.6 \cdot 10^{3} \mathrm{M}^{-1} \mathrm{~cm}^{-1}$.

Lipid peroxidation of mitochondrial membranes was characterized by accumulation of thiobarbituric acid reactive substances (TBARS). After precipitation with trichloroacetic acid, the mitochondria-free supernatant was incubated with $0.2 \%$ thiobarbituric acid in a boiling-water bath for $20 \mathrm{~min}$ [32]. After cooling under tap water, the level of TBARS in probes was monitored spectrophotometrically by measuring the difference in absorption between $532 \mathrm{~nm}$ and $600 \mathrm{~nm}$ wavelengths, and calculated using the molar extinction coefficient $\varepsilon_{532}=1.56 \cdot 10^{5} \mathrm{M}^{-1} \mathrm{~cm}^{-1}$. The content of membrane lipid peroxidation products was expressed as nmol TBARS per mg of protein.

The $\mathrm{NAD}(\mathrm{P}) \mathrm{H}$ and FAD levels in mitochondria were estimated by their autofluorescence in the buffer containing $125 \mathrm{mM} \mathrm{KCl}, 50 \mathrm{mM}$ sucrose, $10 \mathrm{mM}$ Tris- $\mathrm{HCl}, 2.5 \mathrm{mM} \mathrm{KH}_{2} \mathrm{PO}_{4}, 5 \mathrm{mM} \mathrm{MgSO}_{4}$, and $5 \mathrm{mM}$ succinate (or $5 \mathrm{mM}$ glutamate $/ 2.5 \mathrm{mM}$ malate in the case of $\mathrm{NAD}(\mathrm{P})$ $\mathrm{H}), \mathrm{pH} 7.5$, as previously described [33-36]. NAD(P)H and FAD fluorescences were measured at $\lambda_{\mathrm{ex} / \mathrm{em}}=340 / 465 \mathrm{~nm}$ or $\lambda_{\mathrm{ex}}$ / em $=454 / 530 \mathrm{~nm}$, respectively. The coenzyme levels were expressed as fluorescence arbitrary units (FAU).

EGTA at a concentration of $0.5 \mathrm{mM}$ was added to experimental samples immediately before the addition of hypochlorite (25-300 $\mu \mathrm{M})$ when effects of calcium chelator were necessary to be studied.

\subsection{Respiratory activity measurement}

Mitochondrial respiration was determined polarographically at $25^{\circ} \mathrm{C}$ using the Clark-type electrode incorporated in a thermostatic hermetic cell [37]. The mitochondrial suspension $(1 \mathrm{mg} / \mathrm{ml})$ was placed into the cell with the buffer containing $125 \mathrm{mM} \mathrm{KCl}, 50 \mathrm{mM}$ sucrose, $10 \mathrm{mM}$ Tris- $\mathrm{HCl}, 2.5 \mathrm{mM} \mathrm{KH}_{2} \mathrm{PO}_{4}, 5 \mathrm{mM} \mathrm{MgSO}_{4}$, pH 7.2 with or without $0.5 \mathrm{mM}$ EGTA added. $\mathrm{HOCl}(25-300 \mu \mathrm{M})$ was added directly before measurement. Then the substrate succinate $(5 \mathrm{mM})$ and ADP $(180 \mu \mathrm{M})$ were introduced into the mitochondrial suspension sequentially. The duration of sample measurement was $10 \mathrm{~min}$. To characterize the respiratory activity, the rate of oxygen consumption by mitochondria was determined in different metabolic states: $V_{2}$ is substrate-dependent respiratory rate (in the presence of the substrate and the absence of ADP), $V_{3}$ is ADPdependent respiratory rate (in the presence of the substrate and ADP). The parameters of coupling of the mitochondrial oxidation and phosphorylation processes were determined: the acceptor control ratio (ACR) $\left(V_{3} / V_{2}\right)$ and the coefficient of phosphorylation $(\mathrm{ADP} / \mathrm{O}) . \mathrm{V}_{2}$ and $\mathrm{V}_{3}$ were expressed as ngatom oxygen per $\mathrm{mg}$ of protein for a minute.

\subsection{Mitochondrial membrane potential}

Membrane potential of isolated rat liver mitochondria was measured by fluorescence of positively charged lipophilic fluorescent probe safranin $\mathrm{O}$ [38]. The buffer for measurement consisted of

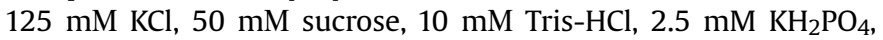
$5 \mathrm{mM} \mathrm{MgSO}_{4}$, and $5 \mathrm{mM}$ succinate, $\mathrm{pH}$ 7.5. The safranin O fluorescence was recorded at $\lambda_{\mathrm{ex} / \mathrm{em}}=495 / 586 \mathrm{~nm}\left(25^{\circ} \mathrm{C}\right)$. In experimental samples, mitochondria $(0.3 \mathrm{mg} / \mathrm{ml})$ were incubated with ruthenim red $(1 \mu \mathrm{M})$, cyclosporine $\mathrm{A}(0.15 \mu \mathrm{M})$, or EGTA $(0.5 \mathrm{mM})$ for $2 \mathrm{~min}$ before $\mathrm{HOCl}(50 \mu \mathrm{M}$ or $200 \mu \mathrm{M})$ was added.

To express in millivolts $(\mathrm{mV})$, the mitochondrial membrane potential values $(\Delta \Psi)$ were determined in the medium containing $250 \mathrm{mM}$ sucrose, $20 \mathrm{mM}$ Tris- $\mathrm{HCl}, \mathrm{pH} 7.2$ [38]. The calibration plot, which represented the dependence of safranin $\mathrm{O}$ fluorescence intensity on the mitochondrial membrane potential value, was calculated according to the Nernst equation:

$$
\Delta \Psi=60 \log \left[\mathrm{K}^{+}\right]_{\text {out }} /\left[\mathrm{K}^{+}\right]_{\text {in }}(\mathrm{mV}),
$$

where $\left[\mathrm{K}^{+}\right]_{\text {in }}$ is the intramitochondrial potassium concentration $(120 \mathrm{mM})$, and $\left[\mathrm{K}^{+}\right]_{\text {out }}$ is the extramitochondrial potassium concentration in the medium that varies from 0 to $20 \mathrm{mM}$ [38,39]. For calibration, the membrane potential values were changed by varying extramitochondrial potassium concentrations in the medium $(0-20 \mathrm{mM})$ in the presence of ionophore valinomycin $(0.28 \mu \mathrm{M})$. Complete depolarization of mitochondria to calibrate the dye fluorescence was achieved by addition of FCCP $(0.5 \mu \mathrm{M})$.

Mitochondrial membrane potential of HeLa cells was measured by fluorescence of cationic dye JC-1 that exhibit potentialdependent accumulation in mitochondria indicated by a fluorescence emission shift from green $(\sim 530 \mathrm{~nm})$ to red $(\sim 590 \mathrm{~nm})$ [40]. Mitochondrial depolarization is indicated by a decrease in the fluorescence intensity ratio $(590 \mathrm{~nm} / 530 \mathrm{~nm})$. The buffer for measurement consisted of $131 \mathrm{mM} \mathrm{NaCl}, 5 \mathrm{mM} \mathrm{KCl}, 1.3 \mathrm{mM} \mathrm{MgSO}$, $6 \mathrm{mM}$ glucose, and $20 \mathrm{mM}$ Hepes, $\mathrm{pH}$ 7.3. The cell suspension contained $10^{6}$ cells per ml. HeLa cells were incubated with JC-1 $(1 \mu \mathrm{M})$ for $15 \mathrm{~min}$ at $37^{\circ} \mathrm{C}$. The fluorescence intensity of JC- 1 was measured spectrofluorimetrically or by epifluorescence microscopy. In the latter case, BK6000 Fluorescence Microscope with a $520 \mathrm{~nm}$ longpass optical filter was used. Regions of high mitochondrial polarization are indicated by orange fluorescence due to the J-aggregate formation by the concentrated dye. Depolarized regions are indicated by green fluorescence of the JC- 1 monomers. Complete depolarization of mitochondria was achieved by addition of FCCP $(0.5 \mu \mathrm{M})$ after JC- 1 loading and before hypochlorite in the case of the corresponding experiment.

\subsection{Mitochondrial swelling}

Rat liver mitochondria swelling was measured spectrophotometrically by the decrease in optical density $\left(D_{520}\right)$ of mitochondrial suspension $(0.4 \mathrm{mg} / \mathrm{ml})$ at $520 \mathrm{~nm}$ on the time $\left(25^{\circ} \mathrm{C}\right)$ using a buffer containing $125 \mathrm{mM}$ sucrose, $60 \mathrm{mM} \mathrm{KCl}, 10 \mathrm{mM}$ Tris- $\mathrm{HCl}$, $1 \mathrm{mM} \mathrm{KH}_{2} \mathrm{PO}_{4}$, and $5 \mathrm{mM}$ succinate, $\mathrm{pH} 7.2$ [41]. Ruthenium red $(1 \mu \mathrm{M})$ or cyclosporine $\mathrm{A}(0.15 \mu \mathrm{M})$ were added $2 \mathrm{~min}$ before $\mathrm{HOCl}$ $(200 \mu \mathrm{M})$. Mitochondrial swelling was determined as maximal rate of decrease in optical density of the mitochondrial suspension [42].

\subsection{Calcium measurements}

Calcium concentration in cell cytoplasm was measured using the $\mathrm{Ca}^{2+}$ probe Fura-2AM [43]. HeLa cells $\left(10^{6}\right.$ per milliliter) in Hepes-buffer containing $131 \mathrm{mM} \mathrm{NaCl}, 5 \mathrm{mM} \mathrm{KCl}, 2.5 \mathrm{mM} \mathrm{CaCl}_{2}$, $1.3 \mathrm{mM} \mathrm{MgSO}_{4}, 6 \mathrm{mM}$ glucose, and $20 \mathrm{mM}$ Hepes, $\mathrm{pH} 7.3$ were incubated with Fura-2AM $(2 \mu \mathrm{M})$ at $37^{\circ} \mathrm{C}$ for $30 \mathrm{~min}$. Thereafter the cells were centrifuged at $150 \mathrm{~g}$ for $5 \mathrm{~min}$, washed and resuspended with Hepes-buffer containing $1 \mu \mathrm{M}$ EGTA and no $\mathrm{CaCl}_{2}$. The amount of cells was determined using an automated cell counter. The fluorescence of Fura-2 was assessed at $510 \mathrm{~nm}$ using two wavelengths of excitation: $340 \mathrm{~nm}$ that corresponded to the $\mathrm{Ca}^{2+}$-bound form of Fura- 2 and $380 \mathrm{~nm}$ that corresponded to the Ca-free form of the probe. For each experiment, $0.1 \%$ Triton X-100 and $1.3 \mathrm{mM} \mathrm{CaCl}_{2}$ were added into control sample to obtain the values of the maximum fluorescence level, and $5 \mathrm{mM}$ EGTA to obtain the minimum fluorescence level at a given concentration of the Fura-2. The concentration of cell calcium was calculated using the equation: 
$\left[\mathrm{Ca}^{2+}\right]_{\mathrm{cyt}}=\mathrm{K}_{\mathrm{d}} *\left[\left(\mathrm{R}-\mathrm{R}_{\min }\right) /\left(\mathrm{R}_{\mathrm{max}}-\mathrm{R}\right)\right] * \mathrm{~S}_{\mathrm{f}} / \mathrm{S}_{\mathrm{b}}$

where $R$ is the ratio of fluorescence intensities at two excitation wavelengths $\left(\mathrm{I}_{340} / \mathrm{I}_{380}\right) ; R_{\max }$ is the $\mathrm{I}_{340} / \mathrm{I}_{380}$ ratio at $\mathrm{Ca}^{2+}$-saturating conditions in the presence of $0.1 \%$ Triton X-100 and $1.3 \mathrm{mM} \mathrm{CaCl}_{2}$; $R_{\min }$ is the $\mathrm{I}_{340} / \mathrm{I}_{380}$ ratio in the presence of $5 \mathrm{mM}$ EGTA that corresponds to the $\mathrm{Ca}^{2+}$-free form of the probe; $S_{f}$ and $S_{b}$ are the baseline fluorescence intensities of Fura- 2 at the excitation wavelength of $380 \mathrm{~nm}$ under $\mathrm{Ca}^{2+}$-free and -bound conditions, respectively; $K_{d}$ for $\mathrm{Ca}^{2+}$ binding to Fura- 2 was assumed to be equal to $220 \mathrm{nM}$ [44]. The figures represent the results of calcium change under hypochlorite action as a difference of the calcium levels before and after hypochlorite addition $\left(\Delta\left[\mathrm{Ca}^{2+}\right], \mathrm{nM}\right)$.

The changes of mitochondrial calcium level in HeLa cells under hypochlorite action were determined using the fluorescent dye XRhod-1-AM $[45,46]$. HeLa cells $\left(10^{6}\right.$ per milliliter $)$ were incubated in Hepes-buffer, pH 7.3, with X-Rhod-1-AM $(2 \mu \mathrm{M})$ at $37^{\circ} \mathrm{C}$ for $15 \mathrm{~min}$. Then they were centrifuged at $150 \mathrm{~g}$ for $5 \mathrm{~min}$, washed and resuspended with Hepes-buffer containing $1 \mu \mathrm{M}$ EGTA and no $\mathrm{CaCl}_{2}$. The fluorescence of X-Rhod-1 was measured at $\lambda_{\mathrm{ex} / \mathrm{em}}=580 /$ $602 \mathrm{~nm}$. The $\mathrm{Ca}^{2+}$ concentration inside the mitochondria was proportional to the fluorescence intensity of X-Rhod-1. The figures represent the $\mathrm{Ca}^{2+}$ level decrease in hypochlorite-treated mitochondria as a difference of the fluorescence intensities before and after hypochlorite addition $(\Delta \mathrm{F})$.

In experimental samples, cells were incubated with each of the inhibitors, ruthenium red (RR, $1 \mu \mathrm{M})$, cyclosporine $\mathrm{A}(\mathrm{Cys} A, 1 \mu \mathrm{M})$, and dantrolene (Dnt, $10 \mu \mathrm{M})$ for $2 \mathrm{~min}$ before $\mathrm{HOCl}(50 \mu \mathrm{M}$ or $200 \mu \mathrm{M}$ ) addition.

The determination of $\mathrm{Ca}^{2+}$ level in isolated rat liver mitochondria was carried out with Fura-2AM as previously described [47]. Initially, mitochondria $(40 \mathrm{mg} / \mathrm{ml})$ were incubated in the isolation buffer with Fura-2AM $(6 \mu \mathrm{M})$ at $25^{\circ} \mathrm{C}$ for $10 \mathrm{~min}$. Then mitochondria were washed, centrifuged at $8,500 \mathrm{~g}$ for $10 \mathrm{~min}\left(4^{\circ} \mathrm{C}\right)$, and resuspended by pipetting with the same volume of isolation buffer without probe. The measurement of Fura-2 fluorescence was performed after addition of mitochondria $(0.4 \mathrm{mg} / \mathrm{ml})$ to the medium containing $125 \mathrm{mM}$ sucrose, $60 \mathrm{mM} \mathrm{KCl}, 10 \mathrm{mM}$ Tris- $\mathrm{HCl}, 1 \mathrm{mM}$ $\mathrm{KH}_{2} \mathrm{PO}_{4}$, and $5 \mathrm{mM}$ succinate, $\mathrm{pH}$ 7.4. The fluorescence of Fura- 2 in isolated mitochondria was assessed at $510 \mathrm{~nm}$ using two excitation wavelengths of $340 \mathrm{~nm}$ and $380 \mathrm{~nm}$. After that the ratio of fluorescence intensities was calculated $\left(\mathrm{I}_{340} / \mathrm{I}_{380}\right)$. The figures represent the mitochondrial calcium level decrease under hypochlorite exposure $(50-300 \mu \mathrm{M})$ as a difference of the ratio $\left(\mathrm{I}_{340} / \mathrm{I}_{380}\right)$ before and after hypochlorite addition $(\Delta \mathrm{F})$.

\subsection{Statistical analysis}

The results of the experiments were expressed as the means of four or five replicates \pm SEM. The differences between the values of parameters measured in groups were analyzed using the Student's t-test or nonparametric Mann-Whitney test depending on the normality of values distribution in the groups. The normality of distribution was determined by Shapiro-Wilk test. Statistical analysis was conducted using the GraphPad Prism 6.0 software package. The results were assumed to be statistically significant compared to the group in the absence of hypochlorite when $\mathrm{P}$ value was less than $0.05(*), 0.01(* *)$ or $0.001(* *)$.

\section{Results}

3.1. Functional activity, antioxidant system and level of calcium of rat liver mitochondria exposed to hypochlorite

In our experiments, we evaluated the effects of hypochlorite on the mitochondrial respiratory activity, antioxidant system, NADH and FADH levels, mPTP formation, mitochondrial membrane potential, and $\mathrm{Ca}^{2+}$-ion level.

The antioxidant system of mitochondria is very important for maintaining the redox balance and, therefore, the functional activity of these organelles. In the absence of calcium chelator EGTA in the incubation medium, the exposure of isolated rat liver mitochondria to hypochlorite $(25-300 \mu \mathrm{M})$ for $10 \mathrm{~min}$ decreased the GSH level in a concentration-dependent manner (Supplementary Fig. 1). In addition, $\mathrm{HOCl}$ caused a significant increase in the mitochondrial GSSP level (by 1.5 fold at a $\mathrm{HOCl}$ concentration of $100 \mu \mathrm{M}$ ) (Supplementary Fig. 3). This kind of oxidative modifications can alter protein functions. It is interesting that we did not observe any changes in the content of lipid peroxidation products (TBARS) during $\mathrm{HOCl}$ exposure (Supplementary Fig. 2). Similar results were demonstrated on macrophages and red blood cells [12,48,49]. In the presence of EGTA, we noticed less pronounced GSH oxidation and GSSP formation without a change in the content of lipid peroxidation products in hypochlorite-treated mitochondria (Supplementary Figs. 1, 2 and 3). One of the possible mechanisms of the EGTA effects can be the binding of calcium ions by chelator and, thereby, preventing of ROS generation in mitochondria. It was shown that calcium uptake of mitochondria led to an increase in the generation of mitochondrial ROS regardless of the metabolic state of the mitochondria [50]. Since hypochlorite also oxidizes glutathione, the protective effect of EGTA on the mitochondria glutathione level was not full.

Mitochondria exposure to $\mathrm{HOCl}(25-300 \mu \mathrm{M})$ in EGTA-free medium resulted in a considerable impairment in mitochondrial respiratory activity within $10 \mathrm{~min}$ (Fig. 1, Supplementary Figs. 2 and 5). Starting from a concentration of $50 \mu \mathrm{M}$, hypochlorite considerably decreased the ADP-dependent respiratory rate $\left(V_{3}\right)$ and the phosphorylation coefficient $(\mathrm{ADP} / \mathrm{O})$, leading to a decline in the efficiency of mitochondrial oxidative phosphorylation and ATP synthesis (Fig. 1 A and B). It should be noted that hypochlorite at all the tested concentrations did not cause a full cessation of ATP synthesis. These changes contributed to the increase in the substrate-dependent respiratory rate $\left(V_{2}\right)$ and decrease in the acceptor control ratio (ACR) (Supplementary Figs. 2 and 5). We showed that in the presence of EGTA in the medium significant alterations in the mitochondrial respiratory activity parameters studied were observed only at high concentrations of $\mathrm{HOCl}$ $(200-300 \mu \mathrm{M})$. At the same time, EGTA attenuated the effects of hypochlorite on the mitochondrial respiratory activity at low concentrations (25-100 $\mu \mathrm{M})$ (Fig. 1, Supplementary Fig. 2). Therefore, the involvement of $\mathrm{Ca}^{2+}$ ions in the hypochlorite-induced damage of mitochondrial respiratory activity was indirectly confirmed by the influence of EGTA on this process.

Also, hypochlorite caused a concentration-dependent increase in the mitochondrial NAD and FAD levels within 10 min which reached maximum values at a hypochlorite concentration of $200 \mu \mathrm{M}$ (Fig. $2 \mathrm{~A}, \mathrm{~B}$ ). The effect of hypochlorite was more pronounced in the case of NAD, for which a significant effect was observed already at $25 \mu \mathrm{M}$ of hypochlorite (data not shown). It should be noted that in the presence of EGTA the effects of hypochlorite were absent (Fig. 2 A, B).

The $\mathrm{HOCl}$ effects on the mitochondrial membrane potential were assessed. $\mathrm{HOCl}$ was shown to induce the mitochondrial depolarization in a dose-dependent manner (Fig. 3, Supplementary Fig. 3). To study the mechanisms of the $\mathrm{HOCl}$ effect, inhibitory analysis was performed using ruthenium red, an inhibitor of mitochondrial calcium uniporter, and cyclosporine A, a common inhibitor of MPTP, and EGTA. All of them decreased the level of mitochondria depolarization, completely restoring the membrane potential at a hypochlorite concentration of $50 \mu \mathrm{M}$ (Supplementary 

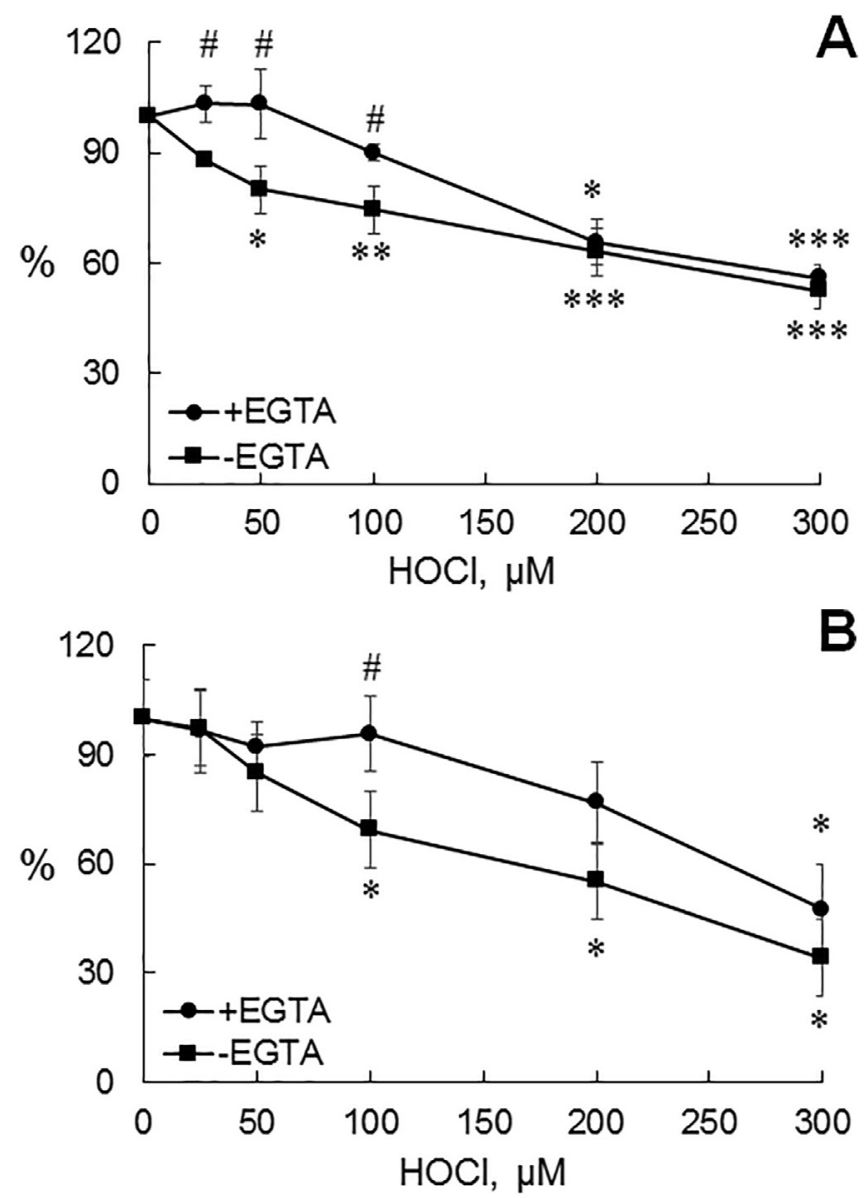

Fig. 1. Effects of hypochlorite on the respiratory activity of rat liver mitochondria. A, ADP-dependent respiratory rate $\left(\mathrm{V}_{3}\right)$; B, phosphorylation coefficient (ADP/O). Mitochondria were incubated without or with $0.5 \mathrm{mM}$ EGTA in the medium $(125 \mathrm{mM} \mathrm{KCl}$, $50 \mathrm{mM}$ sucrose, $10 \mathrm{mM}$ Tris- $\mathrm{HCl}, 2.5 \mathrm{mM} \mathrm{KH_{2 } \mathrm { PO } _ { 4 } , 5 \mathrm { mM } \mathrm { MgSO }} 4, \mathrm{pH} 7.2$ ) at $25^{\circ} \mathrm{C}$. Succinate $(5 \mathrm{mM})$ as oxidation substrate and ADP $(180 \mu \mathrm{M})$ were introduced into the mitochondrial suspension. $\mathrm{HOCl}$ was added directly before measurement. The duration of sample measurement was $10 \mathrm{~min}$. Mitochondria protein concentration was $1 \mathrm{mg} / \mathrm{ml}$. $* \mathrm{p}<0.05, * * \mathrm{p}<0.01, * * * \mathrm{p}<0.001$ vs group in the absence of $\mathrm{HOCl} ; \# \mathrm{p}<0.05$ vs group without EGTA.

Fig. 3), and partially prevented the depolarizing action of hypochlorite at a concentration of $200 \mu \mathrm{M}$ (Fig. 3).

In order to confirm the direct involvement of mitochondrial calcium ions in the mechanisms of hypochlorite action, we studied the permeability transition pore formation and alterations in the content of mitochondrial calcium ions during hypochlorite exposure. In the absence of externally added $\mathrm{Ca}^{2+}, \mathrm{HOCl}$ at a high concentration of $200 \mu \mathrm{M}$ slowly decreased the optical density of the mitochondrial suspension as a result of mitochondrial swelling which indicates MPTP formation (Fig. $4 \mathrm{~A}$ ). Ruthenium red and cyclosporine $\mathrm{A}$, which were added 2 min before $\mathrm{HOCl}$, completely blocked this process. Since there was no externally added calcium, the redistribution of mitochondrial calcium might participate in the mitochondria swelling process under hypochlorite action. This is due to the fact that the mitochondrial suspension derived from the tissue can contain mitochondrial fractions having different thresholds of sensitivity to an oxidizing agent, and a calcium concentration [42]. Therefore, the MPTP formation under the hypochlorite action occurs only in those mitochondrial fractions which are most sensitive to the oxidant. The released calcium is immediately redistributed among other fractions of mitochondria. As a result, some of them reach their calcium threshold at which MPTP

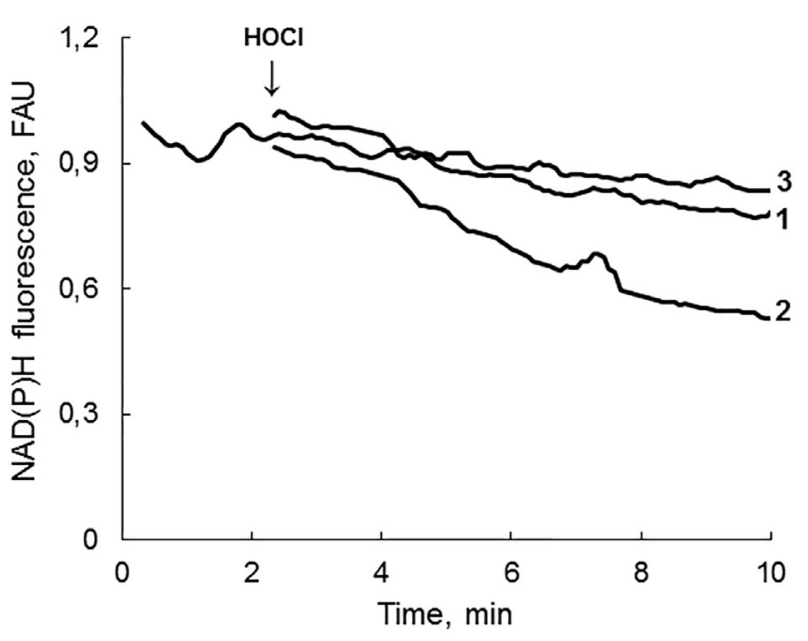

A

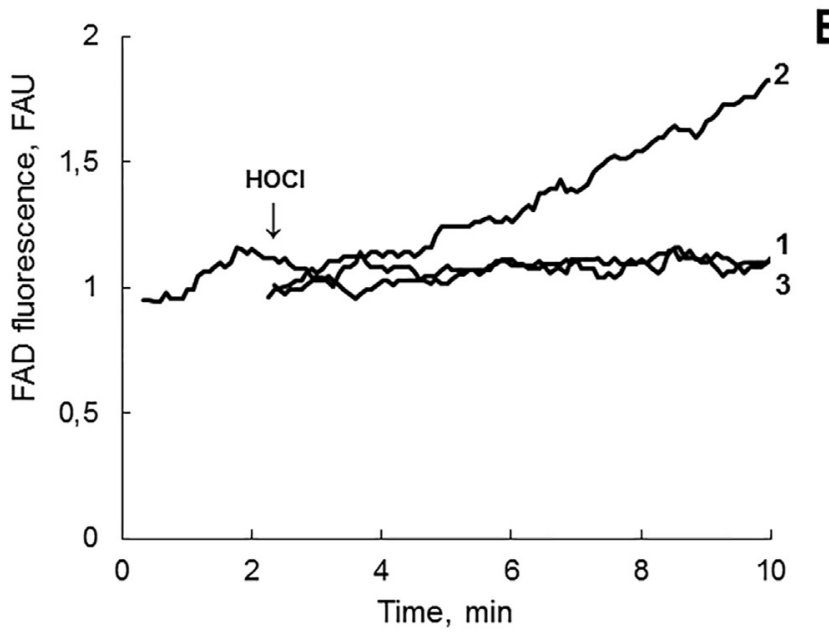

Fig. 2. Mitochondrial $\mathrm{NAD}(\mathrm{P}) \mathrm{H}$ and $\mathrm{FAD}$ levels under hypochlorite action. The substrates used were: A, glutamate $(5 \mathrm{mM}) /$ malate $(2,5 \mathrm{mM})$; B, succinate $(5 \mathrm{mM}) .1$ control, 2-200 $\mu \mathrm{M}$ hypochlorite, 3-200 $\mu \mathrm{M}$ hypochlorite plus $0.5 \mathrm{mM}$ EGTA. Mitochondria were incubated in the medium $(125 \mathrm{mM} \mathrm{KCl}, 50 \mathrm{mM}$ sucrose, $10 \mathrm{mM}$ Tris- $\mathrm{HCl}$, $\left.2.5 \mathrm{mM} \mathrm{KH}_{2} \mathrm{PO}_{4}, 5 \mathrm{mM} \mathrm{MgSO}_{4}, \mathrm{pH} 7.5\right)$ at $25^{\circ} \mathrm{C}$. The duration of sample measurement was $10 \mathrm{~min}$. Mitochondria protein concentration was $0.3 \mathrm{mg} / \mathrm{ml}$. FAU, fluorescence arbitrary units.

opens. Addition of ruthenium red and cyclosporine A prevented the calcium distribution between mitochondria by inhibiting the MCU activity and MPTP formation, which are main pathways of calcium intake and release in mitochondria. At the same time, the almost complete decrease of mitochondrial membrane potential observed in our experiments at a hypochlorite concentration of $200 \mu \mathrm{M}$ was associated not only with the MPTP formation, but also with the alterations in the functional activity of mitochondrial respiratory complexes as a result of oxidative stress. This is confirmed by the absence of complete blocking of the decrease in membrane potential at high concentrations and its restoration at low concentrations (namely $50 \mu \mathrm{M}$ ) of hypochlorite when using inhibitors (Fig. 3, Supplementary Fig. 3).

A direct release of mitochondrial calcium during $\mathrm{HOCl}$ exposure was shown by using the fluorescent probe Fura-2AM (Fig. 4 B). As the concentration increased, hypochlorite was observed to elevate the amount of calcium released out of mitochondria.

Thus, our findings demonstrate that alterations in the mitochondrial functional state under hypochlorite action were associated with the reduction of respiratory activity, increase in the levels of the oxidized forms of NAD and FAD coenzymes, and decrease of 

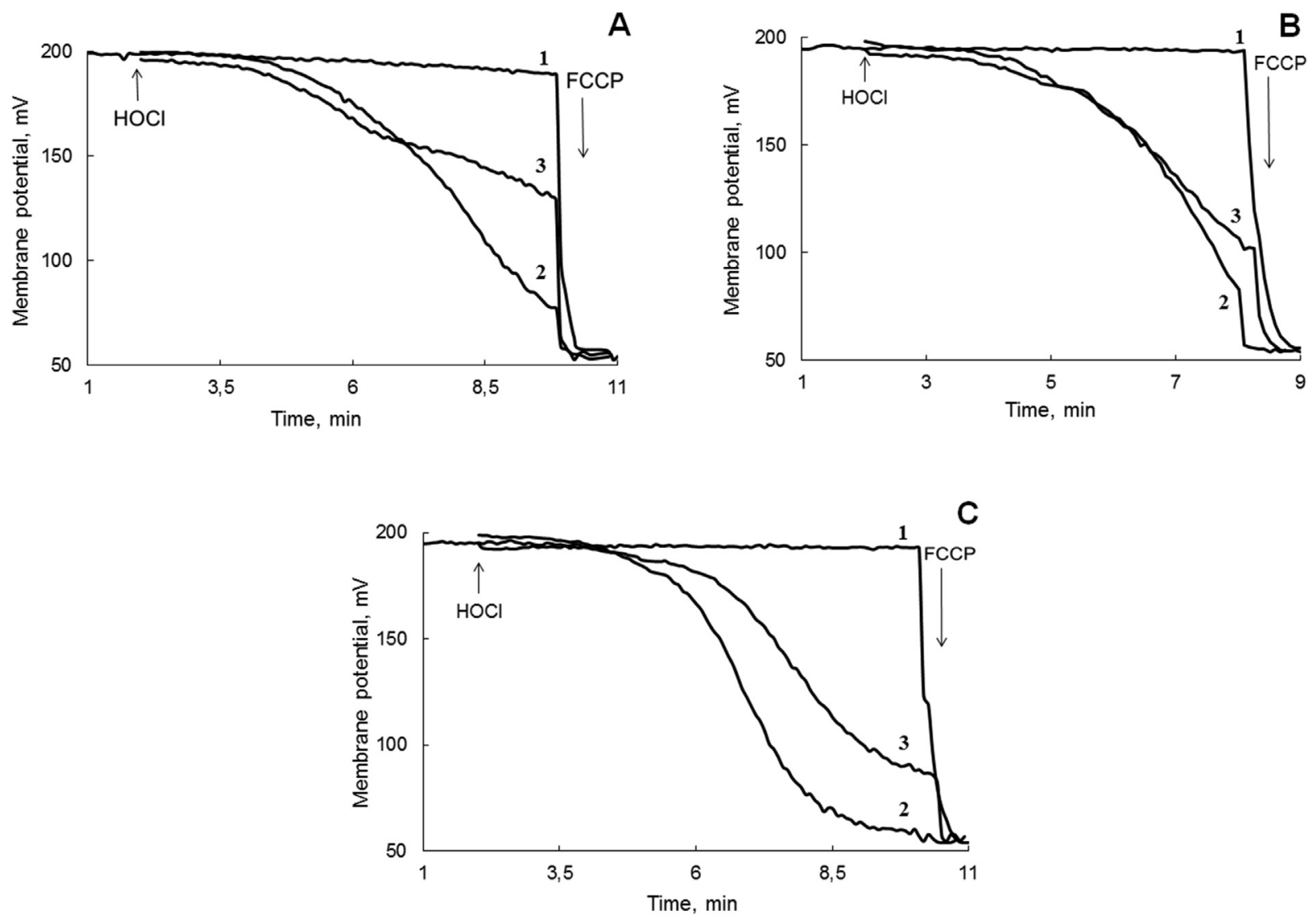

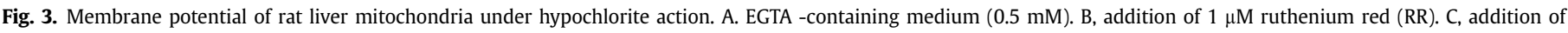

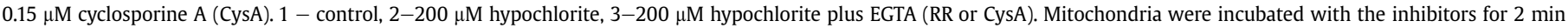
before $\mathrm{HOCl}$ was added. Mitochondria protein concentration was $0.3 \mathrm{mg} / \mathrm{ml}$.

mitochondrial membrane potential. On the one hand, these disorders may be caused by changes in the mitochondrial antioxidant system (reduced glutathione oxidation) and the oxidative damage (glutathionylation) of mitochondrial enzymes. On the other hand, the demonstrated effects of EGTA and inhibitors on the mitochondrial functional activity indicate an essential role of the mitochondrial $\mathrm{Ca}^{2+}$ and membrane permeability transition in the mechanisms of hypochlorite effects, especially at low concentrations. Earlier similar effects as in a case of hypochlorite we demonstrated on the mitochondria exposed to another oxidative agent tert-butyl hydroperoxide [19].

\subsection{Cytoplasmic and mitochondrial calcium levels in HeLa cells exposed to hypochlorite}

At the next stage, we evaluated the intracellular calcium content and the role of mitochondria in the formation of cytoplasmic calcium pool under hypochlorite action using HeLa cells suspension ( $10^{6}$ cells per milliliter) in Hepes-buffer with EGTA.

To study the cytoplasmic calcium content in the cells, we used a Fura-2AM probe, which gets the ability to interact with calcium after its transforming by cytoplasmic esterases into the unesterified form. The resting level of cytosolic calcium measured was about $100 \mathrm{nM}$ that corresponded to the literature data [51]. Hypochlorite dose-dependently caused a pronounced rise in the cytoplasmic calcium content (Fig. $5 \mathrm{~A}$ ). This is in line with other observations $[8,52]$. The calcium content in the cytoplasm reached nearly $200 \mathrm{nM}$ at high concentrations of $\mathrm{HOCl}(200-300 \mu \mathrm{M})\left(\right.$ delta $\left[\mathrm{Ca}^{2+}\right]$ was equal about to $120 \mathrm{nM}$ ). It is noteworthy that because of the absence of exogenous calcium in the incubation medium (in the presence of extracellular EGTA), the increase of calcium content in cell cytoplasm was only due to its release from intracellular stores namely the endoplasmic reticulum and mitochondria. Moreover, the plasma membrane calcium ATPase (PMCA) and sarco/endoplasmic reticulum calcium ATPase (SERCA) have very similar structure, and both are sensitive to oxidative damage due to the protein thiol groups oxidation [53,54]. As a result, the activity of both calcium pumps are decreased because of $\mathrm{HOCl}$-induced cellular SH- groups oxidation. That prevents the removal of excess calcium from the cell cytoplasm.

To assess the dynamics of the mitochondrial calcium changes in HeLa cells under hypochlorite action, we used a X-Rhod-1-AM probe having a net positive charge that promotes its sequestration into mitochondria [46]. A significant decrease of X-Rhod-1 fluorescence caused by the release of mitochondrial $\mathrm{Ca}^{2+}$ was shown after the exposure of cells to hypochlorite at concentrations of $25 \mu \mathrm{M}$ and more (Fig. $5 \mathrm{~B}$ ). At the same time, the mitochondrial membrane potential of HeLa cells was almost unchanged at the given concentrations of hypochlorite that helps to keep unesterified form of the positively charged X-Rhod- 1 within organelles (Supplementary Fig. 4). The $\mathrm{Ca}^{2+}$ release from mitochondria was enhanced as the $\mathrm{HOCl}$ concentration was elevated.

We applied an inhibitory analysis to distinguish the contribution of the endoplasmic reticulum and mitochondria to the increase in cytoplasmic $\mathrm{Ca}^{2+}$ level under hypochlorite action (Fig. 6). In this experiment, we studied the effects of inhibitors on the cytoplasmic and mitochondrial $\mathrm{Ca}^{2+}$ pools of HeLa cells exposed to $\mathrm{HOCl}$ at concentrations of $50 \mu \mathrm{M}$ and $200 \mu \mathrm{M}$. That was due to a difference 

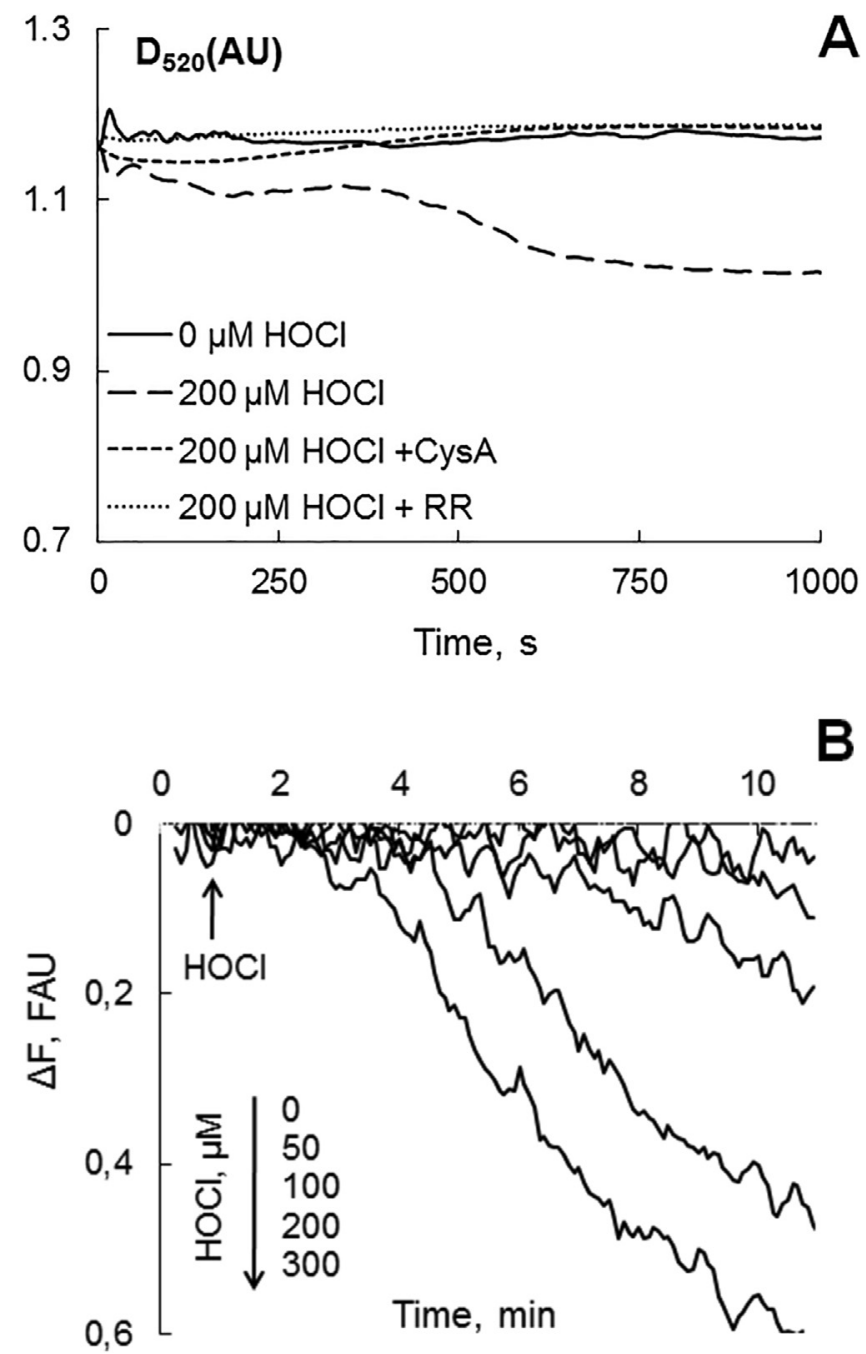

Fig. 4. Swelling and calcium content in hypochlorite-exposed rat liver mitochondria. A. Mitochondrial swelling in the absence of externally added calcium. $1 \mu \mathrm{M}$ Ruthenium red (RR) and $0.15 \mu \mathrm{M}$ cyclosporine A (CysA) were added 2 min before HOCl. B. Mitochondrial calcium release at different concentrations of hypochlorite. $\Delta \mathrm{F}$ represents the amount of calcium released out of mitochondria. Mitochondria protein concentration was $0.4 \mathrm{mg} / \mathrm{ml}$. AU, absorbance units, FAU, fluorescence arbitrary units.

in the degree of mitochondria oxidative damage under hypochlorite action at these concentrations.

A feature of HeLa cells is the presence of two types of calcium channels in the endoplasmic reticulum: $\mathrm{IP}_{3} \mathrm{R}$ and RyR2 receptors $[55,56]$. Both channels are shown to interact with the calcium release out of the endoplasmic reticulum [55,57].

Since ER is considered to be the main store of intracellular calcium [58], we used dantrolene to evaluate its contribution to the formation of the cytoplasmic $\mathrm{Ca}^{2+}$ pool under $\mathrm{HOCl}$ action. Dantrolene is known to be an inhibitor of RyR receptors responsible for calcium release out of the ER [59]. In addition, it was shown that dantrolene is capable to block $\mathrm{IP}_{3} \mathrm{R}$ receptors as well $[60,61]$. Both RyR and $I P_{3} R$ receptors are very similar in their molecular structure and share a high sequence homology in their ion-conducting pore $[62,63]$. Dantrolene can bind to the $\mathrm{IP}_{3} \mathrm{R}$ and RyR receptors by interacting with the $\mathrm{IP}_{3}$-binding domain occured in the structure of both receptors [60]. Furthermore, it is well-known that RyR2 is activated by cytosolic $\mathrm{Ca}^{2+}$ via the process of $\mathrm{Ca}^{2+}$-induced $\mathrm{Ca}^{2+}$ release (CICR) [64]. While $\mathrm{IP}_{3}$ Rs activity is suppressed by supramicromolar concentrations of calcium [57]. Opening of the RyR
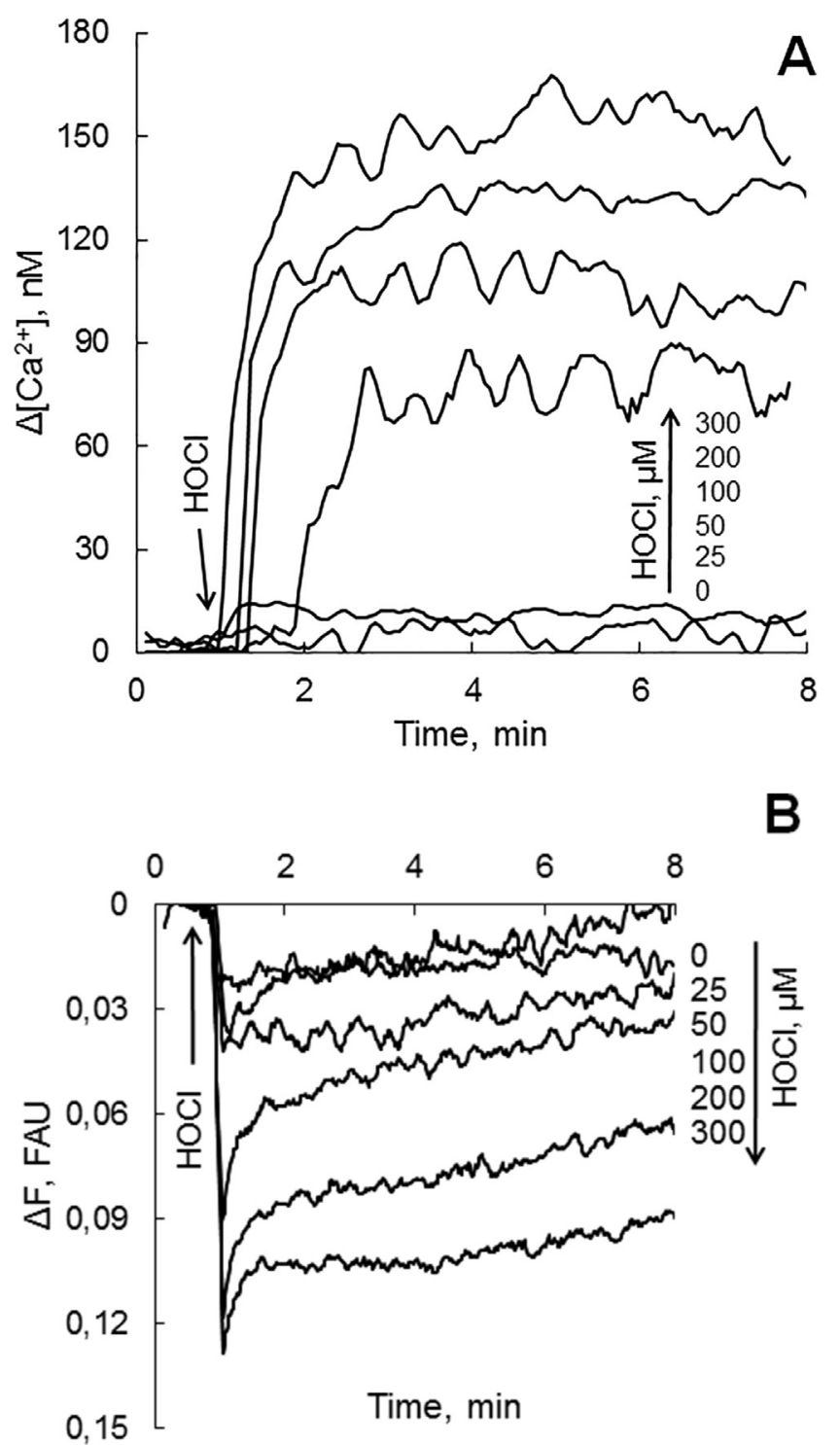

Fig. 5. Calcium level in HeLa cells $\left(10^{6}\right.$ cells per $\left.\mathrm{ml}\right)$ under hypochlorite action. A. Cytoplasmic $\mathrm{Ca}^{2+}$ measurements with Fura-2AM. B. Mitochondrial $\mathrm{Ca}^{2+}$ measurements with X-Rhod-1-AM. Arrow indicates $\mathrm{HOCl}$ addition. FAU, fluorescence arbitrary units.

receptors releases about 20 times more $\mathrm{Ca}^{2+}$ ions than $\mathrm{IP}_{3} \mathrm{Rs}$ [65].

In our studies, dantrolene $(10 \mu \mathrm{M})$ was observed to prevent the $\mathrm{HOCl}$-induced enhancement of cytoplasmic $\mathrm{Ca}^{2+}$ level in HeLa cells at hypochlorite concentrations of $50 \mu \mathrm{M}$ and $200 \mu \mathrm{M}$ (Fig. $6 \mathrm{~A}$ and C). We also used cyclosporine A to assess the involvement of $\mathrm{HOCl}-$ induced calcium leakage out of mitochondria (due to MPTP opening) in cytoplasmic $\mathrm{Ca}^{2+}$ pool. Mitochondria were demonstrated to be able to form mPTPs under $\mathrm{HOCl}$ action [9]. In our studies, cyclosporine $\mathrm{A}(1 \mu \mathrm{M})$ was shown to reduce the cytoplasmic $\mathrm{Ca}^{2+}$ level in HeLa cells after exposure to both $\mathrm{HOCl}$ concentrations by preventing the MPTPs formation and $\mathrm{Ca}^{2+}$ leakage out of mitochondria (Fig. $6 \mathrm{~A}$ and C). Interestingly, cyclosporine A and dantrolene reduced the cytoplasmic $\mathrm{Ca}^{2+}$ level in HeLa cells almost to the same degree (Fig. $6 \mathrm{~A}$ and C). It should also be noted that the effects of inhibitors were less pronounced at a hypochlorite concentration of $200 \mu \mathrm{M}$ rather than $50 \mu \mathrm{M}$ (Fig. $6 \mathrm{~A}$ and $6 \mathrm{C}$, the corresponding curves before and after $\mathrm{HOCl}$ addition in the presence of dantrolene or cyclosporine A). To study the role of mitochondria in the cytoplasmic $\mathrm{Ca}^{2+}$ pool formation, we also applied 

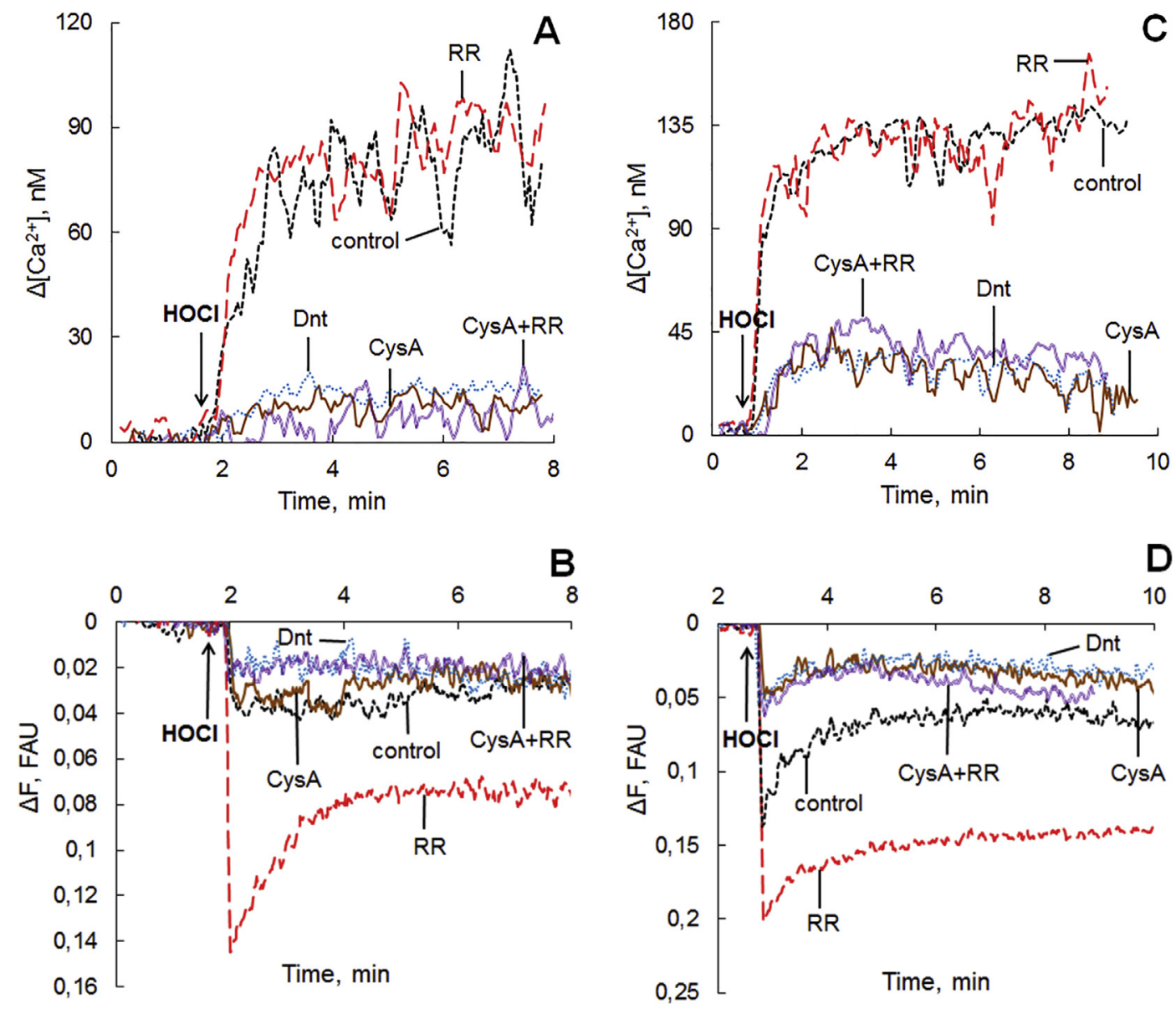

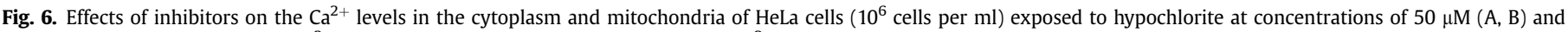

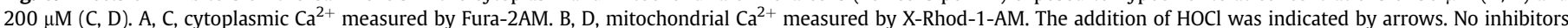

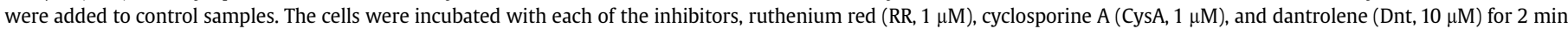
before $\mathrm{HOCl}$ addition. FAU, fluorescence arbitrary units

ruthenium red, which prevents $\mathrm{Ca}^{2+}$ entry into the mitochondria. Ruthenium red $(1 \mu \mathrm{M})$, an inhibitor of MCU, did not change the cytoplasmic $\mathrm{Ca}^{2+}$ level in HeLa cells under HOCl action (Fig. $6 \mathrm{~A}$ and $\mathrm{C})$. The results of ruthenium red and cyclosporine $\mathrm{A}$ coadministration were the same as in the case of using cyclosporine A alone (Fig. $6 \mathrm{~A}$ and $\mathrm{C}$ ). Furthermore, aiming to confirm the participation of mitochondria in the alterations of cytoplasmic calcium under hypochlorite action, we carried out the full mitochondrial depolarization of HeLa cells with FCCP (Supplementary Figs. 5 and 9). Addition of hypochlorite at concentrations of 50 and $200 \mu \mathrm{M}$ to HeLa cells treated by FCCP resulted in a significant increase in the level of cytoplasmic calcium compared to untreated cells (Supplementary Figs. 10 and 11).

In our studies, the same inhibitors were also applied to estimate changes in the mitochondrial $\mathrm{Ca}^{2+}$ pool of HeLa cells under hypochlorite action. Interestingly, both cyclosporine $\mathrm{A}(1 \mu \mathrm{M})$ and dantrolene $(10 \mu \mathrm{M})$ decreased $\mathrm{Ca}^{2+}$ leakage out of mitochondria at hypochlorite concentrations of $50 \mu \mathrm{M}$ and $200 \mu \mathrm{M}$ (Fig. $6 \mathrm{~B}$ and D) that prevented the cytoplasmic $\mathrm{Ca}^{2+}$ increase. It is noteworthy that more significant $\mathrm{HOCl}$-induced $\mathrm{Ca}^{2+}$ leakage out of mitochondria was found in the presence of ruthenium red $(1 \mu \mathrm{M})$ at both hypochlorite concentrations. It is likely, ruthenium red by blocking of MCU prevented the mitochondrial uptake of $\mathrm{Ca}^{2+}$ ions released from endoplasmic reticulum and enhanced the leakage of calcium out of mitochondria. The inhibition of MCU was previously shown to alter local $\mathrm{Ca}^{2+}$ feedback near $\mathrm{IP}_{3} \mathrm{Rs}$ and promote the release of $\mathrm{Ca}^{2+}$ by mitochondria [66,67]. At the same time, co-administration of cyclosporine $\mathrm{A}(1 \mu \mathrm{M})$ and ruthenium red $(1 \mu \mathrm{M})$ eliminated the effect of ruthenium red alone, indicating a key role of mPTPs in the $\mathrm{Ca}^{2+}$ release from mitochondria (Fig. 6 B and D). It should be noted that all these inhibitors did not completely prevent the leakage of calcium out of mitochondria (the curves with dantrolene or cyclosporine A before and after $\mathrm{HOCl}$ addition, Fig. $6 \mathrm{~B}$ and D). This is likely to be caused by occurrence of non-mPTP associated leakage of $\mathrm{Ca}^{2+}$ ions under $\mathrm{HOCl}$ action.

\section{Discussion}

Hypochlorite is an important mediator of inflammatory processes in many pathological conditions [68]. $\mathrm{HOCl}$ causes the death of damaged cells and healthy cells surrounding inflammation sites [5-7]. The mechanisms of hypochlorite effects in cells remain to be confirmed by more detailed studies. Reactions of $\mathrm{HOCl}$ with biological molecules include oxidation and chlorination [10,11]. In our experiments, we studied the mechanisms of cell damage under hypochlorite action, focusing on the role of mitochondria and cellular calcium. Our attention to the study of mitochondrial functional state was stipulated by the fact that mitochondria play a key role in many cellular physiological processes and contain a variety of signaling molecules including $\mathrm{Ca}^{2+}$ ions [13].

Earlier we used human erythrocytes to show that active forms of chlorine (hypochlorite or chloramine) in a concentrationdependent manner $(50-200 \mu \mathrm{M})$ inhibited membrane $\mathrm{Na}^{+}-, \mathrm{K}^{+}-$ and $\mathrm{Mg}^{2+}$ - ATP-ases as well as active glutathione S-conjugate 
efflux, oxidized cellular reduced glutathione and membrane protein thiols and induced complex morphological transformations of cells: swelling, echinocytosis, and haemolysis, but did not induce lipid peroxidation $[49,69]$.

In the present study, hypochlorite at physiologically relevant concentrations induced significant alterations in mitochondrial functional state that was accompanied by variations in respiratory activity, oxidation of GSH, increase of coenzymes NAD and FAD levels, and decrease of membrane potential which stimulates the mPTP opening. It was demonstrated earlier that the exposure of isolated mitochondria to $\mathrm{HOCl}$ in vitro in EDTA-containing medium inhibited the rat liver mitochondria respiratory activity and caused the uncoupling of the respiratory and phosphorylation processes without appreciable changes in the phosphorylation coefficient [70]. The decreased respiration rate at $V_{3}$ state was related to reduced levels of the mitochondrial protein sulfhydryl groups ( $\mathrm{PSH}$ ) and mitochondrial GSH. HOCl significantly inhibited a key enzyme in the Krebs cycle, $\alpha$-ketoglutarate dehydrogenase. This is in line with the conclusions that alterations in the mitochondrial antioxidant system led to damage of enzyme complexes of the respiratory chain and Krebs cycle, cell bioenergetics disturbances, ROS production, and release of proapoptotic factors by mitochondria [13]. Similar effects of hypochlorite on the GSH level have already been demonstrated in different types of human cells $[6,71,72]$. Earlier we concluded that the membrane pore formation and disturbance in passive ion permeability are responsible for the $\mathrm{HOCl}$-induced haemolysis [72]. Previously, it was assumed that the main cause of these disorders was largely hypochlorite-induced oxidative stress [10]. At the same time, we demonstrated that in the presence of EGTA the damaging effects of $\mathrm{HOCl}$ on the functional state of isolated mitochondria were less pronounced and fully eliminated at low concentrations of the oxidant. This reveals the importance of mitochondrial $\mathrm{Ca}^{2+}$ in the mechanisms of hypochlorite effect. One of the possible mechanisms of inhibition of the respiratory activity of rat liver mitochondria, especially at low concentrations of hypochlorite, is direct inhibition of cytochrome $C$ oxidase activity by specific interaction of calcium ions with the cation binding site. It was previously demonstrated that calcium at a concentration of $0.5 \mu \mathrm{M}$ suppressed the activity of liver mitochondria cytochrome oxidase by $50 \%$ [73]. And it is well established that such high levels of calcium can occur in cells only in the space of MAM contacts [74]. Since the calcium uptake by mitochondria leads to the intensification of ROS production, and in the case of calcium overload to the depolarization of mitochondrial membranes and MPTP opening [75-78], the protective effect of EGTA on isolated mitochondria exposed to hypochlorite could be due to the binding of calcium released out of mitochondria, and, therefore, decreasing of ROS production in mitochondria and preventing of the mitochondrial depolarization and cytochrome oxidase inhibition by $\mathrm{Ca}^{2+}$ ions. Because the calcium-induced ROS increase and ROS-mediated calcium vulnerability can create a self-amplifying loop [50,79]. It is known that in mitochondria $\mathrm{Ca}^{2+}$ transport is realized due to the mitochondrial permeability transition pore, mitochondrial calcium uniporter, and sodium/calcium exchanger [80]. Using $\mathrm{Ca}^{2+}$ indicator Fura-2AM, we demonstrated $\mathrm{HOCl}$-induced $\mathrm{Ca}^{2+}$ release out of the isolated liver mitochondria that might be mainly due to MPTP opening. Our present findings pointed out that in the absence of exogenous $\mathrm{Ca}^{2+}$ the mitochondrial swelling was caused by $\mathrm{HOCl}-$ induced redistribution of intramitochondrial $\mathrm{Ca}^{2+}$ as a result of its re-accumulation by other intact mitochondria. That is confirmed by the ruthenium red and cyclosporine A prevention of the isolated mitochondria swelling and membrane depolarization. In addition, mitochondria are able to accumulate a significant amount of cellular $\mathrm{Ca}^{2+}[13,81]$.

Using HeLa cells, we observed a considerable increase in cytoplasmic $\mathrm{Ca}^{2+}$ level and a decrease in mitochondrial one under hypochlorite action. It was earlier shown that the HOCl-induced elevation of cytoplasmic $\mathrm{Ca}^{2+}$ was driven mainly by its entry into the cells from the intercellular space [8]. We can explain the increase in cytoplasmic $\mathrm{Ca}^{2+}$ level only by its release from the cellular stores in EGTA-containing medium (exogenous $\mathrm{Ca}^{2+}$ - free medium) used in our studies. It is assumed that the ER is the main cellular calcium store [58]. $\mathrm{Ca}^{2+}$ leakage from ER cisternae occurs mainly through $\mathrm{Ca}^{2+}$ release channels such as $\mathrm{IP}_{3} \mathrm{R}$ and RyR receptors [18]. As was mentioned above, both channels are contained in HeLa cells. Since dantrolene considerably prevented an increase in cytoplasmic $\mathrm{Ca}^{2+}$ level in our experiments, we confirmed that the ER is the main source of cytoplasmic calcium released under $\mathrm{HOCl}$ action. It is well known that RyR2 receptors are very sensitive to the cell redox status because of having many cysteine residues in a reduced free thiol state per tetrameric channel [64]. In our studies, S-glutathionylation and shifts in the ratios of GSH/GSSG and NADH/NAD+ pairs can increase the ion-conducting ability of RyRs that explains the inhibitory effect of dantrolene [82-84]. Also, $\mathrm{IP}_{3} \mathrm{Rs}$ are up-regulated under oxidative stress by stabilizing the active conformation of the receptor, and they are not inactivated by high intracellular $\mathrm{Ca}^{2+}$ concentrations [20,21]. As stated above, dantrolene is also capable to inhibit $\mathrm{IP}_{3} \mathrm{Rs}$. But dantrolene also prevented calcium release out of mitochondria in HeLa cells. This is due to the fact that because dantrolene prevents the $\mathrm{Ca}^{2+}$ release out of the endoplasmic reticulum, the mitochondria will not be overloaded by $\mathrm{Ca}^{2+}$, and mPTPs will not activate. In its turn, cyclosporine $A$ also prevented the decrease of mitochondrial calcium as well as the increase of cytoplasmic calcium levels in HeLa cells exposed to $\mathrm{HOCl}$. And the effects of cyclosporine A on the cytoplasmic and mitochondrial $\mathrm{Ca}^{2+}$ levels were similar to dantrolene. Moreover, in the case of fully depolarized mitochondria hypochlorite induced more pronounced increase of $\mathrm{Ca}^{2+}$ level in cytoplasm.

These results demonstrated that mitochondria might accumulate $\mathrm{Ca}^{2+}$ released from ER. Mitochondria release calcium by MPTP opening, thereby participating in the formation of the cytoplasmic calcium pool. Since, in the presence of ruthenium red, $\mathrm{HOCl}-$ induced $\mathrm{Ca}^{2+}$ release from mitochondria is enhanced and the cytoplasmic $\mathrm{Ca}^{2+}$ level in HeLa cells does not change, we can assume that there is a redistribution of cytoplasmic $\mathrm{Ca}^{2+}$ between mitochondria. Additionally, it was shown that mitochondria could allow the propagation of $\mathrm{Ca}^{2+}$ signals in their network, independently to the cytoplasm [85].

Our conclusions are supported by the finding that major amount of RyRs and $\mathrm{IP}_{3} \mathrm{Rs}$, which are responsible for $\mathrm{Ca}^{2+}$ release from ER, is concentrated in the area of ER-mitochondria contacts (MAMs) [86-88]. The formation of MAMs, which are characterized by high $\left[\mathrm{Ca}^{2+}\right]$ microdomains, involves $5-20 \%$ of the mitochondrial surface [51]. There is a macromolecular complex containing mitochondrial VDAC proteins, $75 \mathrm{kDa}$ glucose-regulated protein (grp75) and $\mathrm{IP}_{3} \mathrm{R}$ receptors in the area of MAMs. This complex facilitates $\mathrm{Ca}^{2+}$ transfer between the mitochondria and ER [88]. In addition, blocking of mitochondrial $\mathrm{Ca}^{2+}$ uptake with uncouplers in HeLa cells was demonstrated to inhibit $\mathrm{Ca}^{2+}$ release and oscillations because of the increased feedback inhibition by $\mathrm{Ca}^{2+}$ of $\mathrm{IP}_{3} \mathrm{Rs}$ in the absence of $\mathrm{Ca}^{2+}$ uptake by neighbouring mitochondria [89]. Also, MCU is known to be the main transporter of calcium ions into mitochondria. However, MCU has a low affinity for calcium $(\mathrm{Kd} \sim 15-20 \mu \mathrm{M})$ and a high rate of calcium transfer $[51,74,90]$. To transfer calcium ions by MCU into mitochondria, significant concentrations of $\mathrm{Ca}^{2+}$, which arise only in the area of MAM contacts, are required [91]. Furthermore, in the area of such contacts a direct transfer of $\mathrm{Ca}^{2+}$ ions from ER into mitochondria was demonstrated [90]. Also, it was shown that large fraction of the $\mathrm{Ca}^{2+}$ released via RyRs or $\mathrm{IP}_{3} \mathrm{Rs}$ can be taken up by mitochondria [92,93]. 


\subsection{Conclusions}

Hypochlorite impairs the antioxidant system and functional state of mitochondria. In the presence of EGTA and inhibitors of calcium transport, the effect of hypochlorite on the functional state of mitochondria is decreased. The present study provides an evidence that the changes in mitochondrial $\mathrm{Ca}^{2+}$ level are important part of the mechanisms of $\mathrm{HOCl}$-mediated damage, especially at low hypochlorite concentrations. Our findings show that in cells exposed to $\mathrm{HOCl}$ mitochondria play a key role in the redistribution of cytoplasmic $\mathrm{Ca}^{2+}$ and act as mediators of $\mathrm{Ca}^{2+}$ release from ER into the cellular cytoplasm.

\section{Funding}

This research did not receive any specific grant from funding agencies in the public, commercial, or not-for-profit sectors.

This research was performed under the financial support and with using of equipment of Polessky State University, Yanka Kupala State University of Grodno and Belarusian State University.

\section{Author contributions}

V.T. Cheshchevik conceived of the conception of the work, planned the experiments and wrote manuscript.

N.G. Krylova contributed to the design and implementation of the studies of calcium level in HeLa cells, collected and analyzed the data.

G.N. Semenkova contributed to the design and implementation of the studies of calcium level in HeLa cells, collected and analyzed the data.

N.G. Cheshchevik contributed to the implementation of the experiments with the animals and isolated rat liver mitochondria, collected and analyzed the data.

E.A. Lapshina contributed to the design of the experiments with the isolated rat liver mitochondria, collected and analyzed the data.

I.B. Zavodnik took part in writing the manuscript, discussing the results and substantiating key ideas.

All authors provided critical feedback and helped shape the research, analysis and manuscript.

All authors have approved the final version of manuscript submitted to the Biochimie.

\section{Appendix A. Supplementary data}

Supplementary data to this article can be found online at https://doi.org/10.1016/j.biochi.2021.02.009.

\section{References}

[1] J. Kucharská, Z. Braunová, O. Uličná, L. Zlatoś, A. Gvozdjáková, Deficit of Coenzyme Q in heart and liver mitochondria of rats with streptozotocin-induced diabetes, Physiol. Res. 49 (2000) 411-418.

[2] M. Hussien, R.J. Delecata, P.D. Carey, Neutrophil hypochlorous acid production is impaired in multiple organ failure patients with candidaemia; reversal with antifungal agents, Inflamm. Res. 51 (2002) 213-217, https://doi.org/10.1007/ Pl00000295.

[3] C.C. King, M.M. Jefferson, E.L. Thomas, Secretion and inactivation of myeloperoxidase by isolated neutrophils, J. Leukoc. Biol. 61 (1997) 293-302. http:// www.ncbi.nlm.nih.gov/pubmed/9060452\%5Cnhttp://www.jleukbio.org/ content/61/3/293.full.pdf.

[4] N.M. Domigan, T.S. Charlton, M.W. Duncan, C.C. Winterbourn, A.J. Kettle, Chlorination of tyrosyl residues in peptides by myeloperoxidase and human neutrophils, J. Biol. Chem. (1995), https://doi.org/10.1074/jbc.270.28.16542.

[5] J.S. Gujral, A. Farhood, M.L. Bajt, H. Jaeschke, Neutrophils aggravate acute liver injury during obstructive cholestasis in bile duct-ligated mice, Hepatology 38 (2003) 355-363, https://doi.org/10.1053/jhep.2003.50341.

[6] M. Whiteman, J.P.E. Spencer, H.H. Szeto, J.S. Armstrong, Do mitochondriotropic antioxidants prevent chlorinative stress-induced mitochondrial and cellular injury? Antioxidants Redox Signal. 10 (2008) 641-650, https:// doi.org/10.1089/ars.2007.1879.

[7] K.E. Brown, E.M. Brunt, J.W. Heinecke, Immunohistochemical detection of myeloperoxidase and its oxidation products in Kupffer cells of human liver, Am. J. Pathol. 159 (2001), https://doi.org/10.1016/S0002-9440(10)63059-3, 2081-8.

[8] Y.T. Yang, M. Whiteman, S.P. Gieseg, HOCl causes necrotic cell death in human monocyte derived macrophages through calcium dependent calpain activation, Biochim. Biophys. Acta Mol. Cell Res. 1823 (2012) 420-429, https:// doi.org/10.1016/j.bbamcr.2011.09.019.

[9] M. Whiteman, P. Rose, J.L. Siau, N.S. Cheung, G.S. Tan, B. Halliwell, J.S. Armstrong, Hypochlorous acid-mediated mitochondrial dysfunction and apoptosis in human hepatoma HepG2 and human fetal liver cells: role of mitochondrial permeability transition, Free Radic. Biol. Med. 38 (2005) 1571-1584, https://doi.org/10.1016/j.freeradbiomed.2005.02.030.

[10] J.M. Pullar, M.C. Vissers, C.C. Winterbourn, Living with a killer: the effects of hypochlorous acid on mammalian cells, IUMB Life 50 (2000) 259-266, https://doi.org/10.1080/713803731.

[11] S. Vicca, Z.A. Massy, C. Hennequin, D. Rihane, T.B. Drüeke, B. Lacour, Apoptotic pathways involved in U937 cells exposed to LDL oxidized by hypochlorous acid, Free Radic. Biol. Med. 35 (2003) 603-615, https://doi.org/10.1016/ S0891-5849(03)00361-7.

[12] M.C.M. Vissers, A. Stern, F. Kuypers, J. Van Den Berg, C.C. Winterbourn, Membrane changes associated with lysis of red blood cells by hypochlorous acid, Free Radic. Biol. Med. 16 (1994) 703-712, https://doi.org/10.1016/08915849(94)90185-6.

[13] M.R. Duchen, Mitochondria in health and disease: perspectives on a new mitochondrial biology, Mol. Aspect. Med. 25 (2004) 365-451, https://doi.org/ 10.1016/j.mam.2004.03.001.

[14] N. Konno, K.J. Kako, Effects of hydrogen peroxide and hypochlorite on membrane potential of mitochondria in situ in rat heart cells, Can. J. Physiol. Pharmacol. (1991), https://doi.org/10.1139/y91-253.

[15] Y.T. Yang, M. Whiteman, S.P. Gieseg, Intracellular glutathione protects human monocyte-derived macrophages from hypochlorite damage, Life Sci. 90 (2012) 682-688, https://doi.org/10.1016/j.lfs.2012.03.002.

[16] G. Ermak, K.J.A. Davies, Calcium and oxidative stress: from cell signaling to cell death, Mol. Immunol. (2002), https://doi.org/10.1016/S0161-5890(01)001080 .

[17] P.S. Brookes, V.M. Darley-Usmar, Role of calcium and superoxide dismutase in sensitizing mitochondria to peroxynitrite-induced permeability transition, Am. J. Physiol. Heart Circ. Physiol. 286 (2004) H39-H46, https://doi.org/ 10.1152/ajpheart.00742.2003.

[18] A. Görlach, K. Bertram, S. Hudecova, O. Krizanova, Calcium and ROS: a mutual interplay, Redox Biol 6 (2015) 260-271, https://doi.org/10.1016/ j.redox.2015.08.010.

[19] I.B. Zavodnik, I.K. Dremza, V.T. Cheshchevik, E.A. Lapshina, M. Zamaraewa, Oxidative damage of rat liver mitochondria during exposure to t-butyl hydroperoxide. Role of Ca2 + ions in oxidative processes, Life Sci. 92 (2013), https://doi.org/10.1016/j.lfs.2013.04.009.

[20] S. Kaja, R.S. Duncan, S. Longoria, J.D. Hilgenberg, J. Payne, N.M. Desai, R. Parikh, S.L. Burroughs, E. V Gregg, D.L. Goad, P. Koulen, Novel mechanism of increased $\mathrm{Ca}(2+)$ release following oxidative stress in neuronal cells involves type 2 inositol-1,4,5-trisphosphate receptors, Neuroscience 175 (2011) 281-291, https://doi.org/10.1016/j.neuroscience.2010.11.010.

[21] J.T. Lock, W.G. Sinkins, W.P. Schilling, Effect of protein S-glutathionylation on $\mathrm{Ca} 2+$ homeostasis in cultured aortic endothelial cells, Am. J. Physiol. Heart Circ. Physiol. 300 (2011) H493-H506, https://doi.org/10.1152/ ajpheart.01073.2010.

[22] C. Giorgi, F. Baldassari, A. Bononi, M. Bonora, E. De Marchi, S. Marchi, S. Missiroli, S. Patergnani, A. Rimessi, J.M. Suski, M.R. Wieckowski, P. Pinton, Mitochondrial Ca2+ and apoptosis, Cell Calcium 52 (2012) 36-43, https:// doi.org/10.1016/j.ceca.2012.02.008.

[23] T.R. Figueira, M.H. Barros, A. Camargo, R.F. Castilho, J.C.B. Ferreira, A.J. Kowaltowski, F.E. Sluse, N.C. Souza-Pinto, A.E. Vercesi, Mitochondria as a source of reactive oxygen and nitrogen species: from molecular mechanisms to human health, Antioxidants Redox Signal. 18 (2013) 2029-2074, https:// doi.org/10.1089/ars.2012.4729.

[24] P.S. Brookes, Y. Yoon, J.L. Robotham, M.W. Anders, S.S. Sheu, Calcium, ATP, and ROS: a mitochondrial love-hate triangle, AJP Cell Physiol. 287 (2004) C817-C833, https://doi.org/10.1152/ajpcell.00139.2004.

[25] A.A. Starkov, C. Chinopoulos, G. Fiskum, Mitochondrial Calcium and Oxidative Stress as Mediators of Ischemic Brain Injury, Cell Calcium, 2004, https:// doi.org/10.1016/j.ceca.2004.02.012.

[26] G. Kroemer, L. Galluzzi, C. Brenner, Mitochondrial membrane permeabilization in cell death, Physiol. Rev. 87 (2007) 99-163, https://doi.org/10.1152/ physrev.00013.2006.

[27] C. Mammucari, R. Rizzuto, Signaling pathways in mitochondrial dysfunction and aging, Mech. Ageing Dev. 131 (2010) 536-543, https://doi.org/10.1016/ j.mad.2010.07.003.

[28] J.M. Graham, Isolation of mitochondria from tissues and cells by differential centrifugation, Curr. Protoc. Cell Biol. Chapter 3 (2001), https://doi.org/ 10.1002/0471143030.cb0303s04. Unit 3.3.

[29] O.H. Lowry, N.J. Rosebrough, A.L. Farr, R.J. Randall, Protein measurement with the Folin phenol reagent, J. Biol. Chem. 193 (1951) 265-275, https://doi.org/ 10.1016/0304-3894(92)87011-4. 
[30] G.L. Ellman, Tissue sulfhydryl groups, in: Arch. Biochem. Biophys., 1959, pp. 70-77, https://doi.org/10.1016/0003-9861(59)90090-6.

[31] R. Rossi, E. Cardaioli, A. Scaloni, G. Amiconi, P. Di Simplicio, Thiol groups in proteins as endogenous reductants to determine glutathione-protein mixed disulphides in biological systems, BBA - Gen. Subj. 1243 (1995) 230-238, https://doi.org/10.1016/0304-4165(94)00133-I.

[32] J. Stocks, T.L. Dormandy, The autoxidation of human red cell lipids induced by hydrogen peroxide, Br. J. Haematol. 20 (1971) 95-111. http://www.ncbi.nlm. nih.gov/pubmed/5540044. (Accessed 6 October 2016).

[33] H.V. Danylovych, Evaluation of functioning of mitochondrial electron transport chain with NADH and FAD autofluorescence, Ukrainian Biochem. J. (2016), https://doi.org/10.15407/ubj88.01.031.

[34] Y. Kushnareva, A.N. Murphy, A. Andreyev, Complex I-mediated reactive oxygen species generation: modulation by cytochrome $\mathrm{c}$ and $\mathrm{NAD}(\mathrm{P})+$ oxidation-reduction state, Biochem. J. (2002), https://doi.org/10.1042/ BJ20021121.

[35] Y. Liu, G. Fiskum, D. Schubert, Generation of reactive oxygen species by the mitochondrial electron transport chain, J. Neurochem. (2002), https://doi.org/ 10.1046/j.0022-3042.2002.00744.x.

[36] C.W. Shuttleworth, Use of NAD(P)H and flavoprotein autofluorescence transients to probe neuron and astrocyte responses to synaptic activation, Neurochem. Int. (2010), https://doi.org/10.1016/j.neuint.2009.12.015.

[37] I.K. Dremza, E.A. Lapshina, J. Kujawa, I.B. Zavodnik, Oxygen-related processes in red blood cells exposed to tert-butyl hydroperoxide, Redox Rep. (2006), https://doi.org/10.1179/135100006X116709.

[38] K.E.O. Akerman, M.K.F. Wikström, Safranine as a probe of the mitochondrial membrane potential, FEBS Lett. 68 (1976) 191-197, https://doi.org/10.1016/ 0014-5793(76)80434-6.

[39] L. Moore, W.D. Bonner, Measurements of membrane potentials in plant mitochondria with the safranine method, Plant Physiol. 70 (1982) 1271-1276. http://www.pubmedcentral.nih.gov/articlerender.fcgi? artid=1065874\&amp; tool=pmcentrez\&amp;rendertype =abstract.

[40] M. Reers, T.W. Smith, L.B. Chen, J-aggregate formation of a carbocyanine as a quantitative fluorescent indicator of membrane potential, Biochemistry (1991), https://doi.org/10.1021/bi00232a015.

[41] V. Petronilli, C. Cola, S. Massari, R. Colonna, P. Bernardi, Physiological effectors modify voltage sensing by the cyclosporin A- sensitive permeability transition pore of mitochondria, J. Biol. Chem. 268 (1993) 21939-21945.

[42] S.V. Baranov, I.G. Stavrovskaya, A.M. Brown, A.M. Tyryshkin, B.S. Kristal, Kinetic model for $\mathrm{Ca} 2+$-induced permeability transition in energized liver mitochondria discriminates between inhibitor mechanisms, J. Biol. Chem. 283 (2008) 665-676, https://doi.org/10.1074/jbc.M703484200.

[43] R. Hirst, C. Harrison, K. Hirota, D.G. Lambert, Measurement of $\left[\mathrm{Ca}^{2}+\right] \mathrm{i}$ in whole cell suspensions using fura-2, Methods Mol. Biol. 312 (2005) 37-45, https:// doi.org/10.1385/1-59259-949-4:037.

[44] G. Grynkiewicz, M. Poenie, R.Y. Tsien, A new generation of Ca2+ indicators with greatly improved fluorescence properties, J. Biol. Chem. (1985).

[45] T.I. Peng, J.T. Greenamyre, Privileged access to mitochondria of calcium influx through N-methyl-D-aspartate receptors, Mol. Pharmacol. 53 (1998) 974-980. http://www.ncbi.nlm.nih.gov/pubmed/9614198.

[46] R.M. Drummond, R.A. Tuft, Release of $\mathrm{Ca} 2+$ from the sarcoplasmic reticulum increases mitochondrial $[\mathrm{Ca} 2+]$ in rat pulmonary artery smooth muscle cells, J. Physiol. 516 (1999) 139-147, https://doi.org/10.1111/j.1469-
7793.1999.139aa.x.

[47] G.L. Lukács, A. Kapus, Measurement of the matrix free Ca2+ concentration in heart mitochondria by entrapped fura-2 and quin2, Biochem. J. 248 (1987) 609-613. http://www.pubmedcentral.nih.gov/articlerender.fcgi? artid=1148585\&amp; tool=pmcentrez\&amp;rendertype $=$ abstract.

[48] I.U. Schraufstatter, K. Browne, A. Harris, P.A. Hyslop, J.H. Jackson, O. Quehenberger, C.G. Cochrane, Mechanisms of hypochlorite injury of target cells, J. Clin. Invest. 85 (1990) 554-562, https://doi.org/10.1172/JCI114472.

[49] I.B. Zavodnik, E.A. Lapshina, L.B. Zavodnik, G. Bartosz, M. Soszynski, M. Bryszewska, Hypochlorous acid damages erythrocyte membrane proteins and alters lipid bilayer structure and fluidity, Free Radic. Biol. Med. 30 (2001) 363-369, https://doi.org/10.1016/S0891-5849(00)00479-2.

[50] R.F. Feissner, J. Skalska, W.E. Gaum, S.S. Sheu, Crosstalk signaling between mitochondrial Ca2+ and ROS, Front. Biosci. (2009), https://doi.org/10.2741/ 3303.

[51] R. Rizzuto, Close contacts with the endoplasmic reticulum as determinants of mitochondrial Ca2+ responses, Science 280 (80) (1998) 1763-1766, https:// doi.org/10.1126/science.280.5370.1763.

[52] M. Strosová, M. Skuciová, L. Horáková, Oxidative damage to Ca2+-ATPase sarcoplasmic reticulum by $\mathrm{HOCl}$ and protective effect of some antioxidants, Biofactors 24 (2005) 111-116. http://www.ncbi.nlm.nih.gov/pubmed/ 16403970.

[53] A. Zaidi, L. Barŕon, V.S. Sharov, C. Schöneich, E.K. Michaelis, M.L. Michaelis, Oxidative Inactivation of Purified Plasma Membrane Ca2+-ATPase by Hydrogen Peroxide and Protection by Calmodulin $\dagger, 2003$, https://doi.org/ 10.1021/BI034565U.

[54] N.L. Cook, H.M. Viola, V.S. Sharov, L.C. Hool, C. Schöneich, M.J. Davies, Myeloperoxidase-derived oxidants inhibit sarco/endoplasmic reticulum Ca2+ATPase activity and perturb $\mathrm{Ca} 2+$ homeostasis in human coronary artery endothelial cells, Free Radic. Biol. Med. (2012), https://doi.org/10.1016/ j.freeradbiomed.2011.12.001.

[55] D.L. Bennett, T.R. Cheek, M.J. Berridge, H. De Smedt, J.B. Parys, L. Missiaen,
M.D. Bootman, Expression and function of ryanodine receptors in nonexcitable cells, J. Biol. Chem. 271 (1996) 6356-6362, https://doi.org/10.1074/ jbc.271.11.6356.

[56] R. Sauve, A. Diarra, M. Chahine, C. Simoneau, N. Morier, G. Roy, Ca2+ oscillations induced by histamine $\mathrm{H} 1$ receptor stimulation in HeLa cells: fura- 2 and patch clamp analysis, Cell Calcium 12 (1991) 165-176, https://doi.org/ 10.1016/0143-4160(91)90018-A.

[57] I. Bezprozvanny, J. Watras, B.E. Ehrlich, Bell-shaped calcium-response curves of Ins(1,4,5)P3- and calcium-gated channels from endoplasmic reticulum of cerebellum, Nature 351 (1991) 751-754, https://doi.org/10.1038/351751a0.

[58] F.L. Bygrave, A. Benedetti, What is the concentration of calcium ions in the endoplasmic reticulum? Cell Calcium 19 (1996) 547-551, https://doi.org/ 10.1016/S0143-4160(96)90064-0.

[59] R. Zucchi, S. Ronca-Testoni, The sarcoplasmic reticulum Ca2+ channel/ryanodine receptor: modulation by endogenous effectors, drugs and disease states, Pharmacol. Rev. 49 (1997) 1-51.

[60] N. Ansari, H. Hadi-Alijanvand, M. Sabbaghian, M. Kiaei, F. Khodagholi, Interaction of 2-APB, dantrolene, and TDMT with IP3R and RyR modulates ER stress-induced programmed cell death I and II in neuron-like PC12 cells: an experimental and computational investigation, J. Biomol. Struct. Dyn. 32 (2014) 1211-1230, https://doi.org/10.1080/07391102.2013.812520.

[61] D. MacMillan, S. Chalmers, T.C. Muir, J.G. McCarron, IP3-mediated Ca2+ increases do not involve the ryanodine receptor, but ryanodine receptor antagonists reduce IP3-mediated Ca2 + increases in Guinea-pig colonic smooth muscle cells, J. Physiol. 569 (2005) 533-544, https://doi.org/10.1113/ jphysiol.2005.096529.

[62] F.J. Amador, P.B. Stathopulos, M. Enomoto, M. Ikura, Ryanodine receptor calcium release channels: lessons from structure-function studies, FEBS J. (2013) 5456-5470, https://doi.org/10.1111/febs.12194.

[63] F.X. Boittin, N. Macrez, G. Halet, J. Mironneau, Norepinephrine-induced $\mathrm{Ca}(2+)$ waves depend on $\operatorname{Ins} \mathrm{P}(3)$ and ryanodine receptor activation in vascular myocytes, Am. J. Physiol. 277 (1999) C139-C151.

[64] A.V. Zima, L.A. Blatter, Redox regulation of cardiac calcium channels and transporters, Cardiovasc. Res. 71 (2006) 310-321, https://doi.org/10.1016/ j.cardiores.2006.02.019.

[65] S. Kiviluoto, T. Vervliet, H. Ivanova, J.P. Decuypere, H. De Smedt, L. Missiaen, G. Bultynck, J.B. Parys, Regulation of inositol 1,4,5-trisphosphate receptors during endoplasmic reticulum stress, Biochim. Biophys. Acta Mol. Cell Res. 1833 (2013) 1612-1624, https://doi.org/10.1016/j.bbamcr.2013.01.026.

[66] T.E. Gunter, L. Buntinas, G. Sparagna, R. Eliseev, K. Gunter, Mitochondrial calcium transport: mechanisms and functions, Cell Calcium 28 (2000) 285-296, https://doi.org/10.1054/ceca.2000.0168.

[67] C.S. Rossi, F.D. Vasington, E. Carafoli, The effect of ruthenium red on the uptake and release of $\mathrm{Ca} 2+$ by mitochondria, Biochem. Biophys. Res. Commun. 50 (1973) 846-852, https://doi.org/10.1016/0006-291X(73)91322-3.

[68] F.H. Epstein, S.J. Weiss, Tissue destruction by neutrophils, N. Engl. J. Med. 320 (1989) 365-376, https://doi.org/10.1056/NEJM198902093200606.

[69] M. Soszyński, I.B. Zavodnik, L.B. Zavodnik, L. Ylinska, G. Bartosz, M. Bryszewska, Hypochlorous acid inhibits glutathione S-conjugate export from human erythrocytes, Biochim. Biophys. Acta Biomembr. 1564 (2002) 479-486, https://doi.org/10.1016/S0005-2736(02)00500-X.

[70] Y.Z. Maksimchik, I.K. Dremza, E.A. Lapshina, V.T. Cheshchevik, E.J. Sudnikovich, S.V. Zabrodskaya, I.B. Zavodnik, Rat liver mitochondria impairments under acute carbon tetrachloride-induced intoxication. Effects of melatonin, Biochem. Suppl. Ser. A Membr. Cell Biol. 4 (2010), https://doi.org/ 10.1134/S1990747810020091.

[71] L. Carroll, D.I. Pattison, S. Fu, C.H. Schiesser, M.J. Davies, C.L. Hawkins, Reactivity of selenium-containing compounds with myeloperoxidase-derived chlorinating oxidants: second-order rate constants and implications for biological damage, Free Radic. Biol. Med. 84 (2015) 279-288, https://doi.org/ 10.1016/j.freeradbiomed.2015.03.029.

[72] L.B. Zavodnik, I.B. Zavodnik, E.A. Lapshyna, V.U. Buko, M.J. Bryszewska, Hypochlorous acid-induced membrane pore formation in red blood cells, Bioelectrochemistry 58 (2002) 157-161, https://doi.org/10.1016/S15675394(02)00151-2.

[73] T. Vygodina, A. Kirichenko, A.A. Konstantinov, Direct regulation of cytochrome c oxidase by calcium ions, PloS One (2013), https://doi.org/10.1371/ journal.pone.0074436.

[74] D.G. Nicholls, Mitochondria and calcium signaling, Cell Calcium 38 (2005) 311-317, https://doi.org/10.1016/j.ceca.2005.06.011.

[75] E. Cadenas, A. Boveris, Enhancement of hydrogen peroxide formation by protophores and ionophores in antimycin-supplemented mitochondria, Biochem. J. (1980), https://doi.org/10.1042/bj1880031.

[76] A.J. Kowaltowski, E.S. Naia-Da-Silva, R.F. Castilho, A.E. Vercesi, Ca2+-stimulated mitochondrial reactive oxygen species generation and permeability transition are inhibited by dibucaine or Mg2+, Arch. Biochem. Biophys. (1998) https://doi.org/10.1006/abbi.1998.0870.

[77] L. Tretter, V. Adam-Vizi, Generation of reactive oxygen species in the reaction catalyzed by $\alpha$-ketoglutarate dehydrogenase, J. Neurosci. (2004), https:/| doi.org/10.1523/JNEUROSCI.1842-04.2004.

[78] M.J. Hansson, R. Månsson, S. Morota, H. Uchino, T. Kallur, T. Sumi, N. Ishii, M. Shimazu, M.F. Keep, A. Jegorov, E. Elmér, Calcium-induced generation of reactive oxygen species in brain mitochondria is mediated by permeability transition, Free Radic. Biol. Med. (2008), https://doi.org/10.1016/ j.freeradbiomed.2008.04.021. 
[79] T.I. Peng, M.J. Jou, Oxidative stress caused by mitochondrial calcium overload, Ann. N. Y. Acad. Sci. 1201 (2010) 183-188, https://doi.org/10.1111/j.17496632.2010.05634.x

[80] L. Boyman, H. Mikhasenko, R. Hiller, D. Khananshvili, Kinetic and equilibrium properties of regulatory calcium sensors of NCX1 protein, J. Biol. Chem. 284 (2009) 6185-6191, https://doi.org/10.1074/jbc.M809012200.

[81] G. Santulli, A.R. Marks, Essential roles of intracellular calcium release channels in muscle, brain, metabolism, and aging, Curr. Mol. Pharmacol. 8 (2015) 206-222. http://www.ncbi.nlm.nih.gov/pubmed/25966694.

[82] M. Fill, J. Copello, Ryanodine receptor calcium release channels, Physiol. Rev. 82 (2002) 893-922, https://doi.org/10.1152/physrev.00013.2002.

[83] C. Hidalgo, P. Donoso, M.A. Carrasco, The ryanodine receptors Ca2+ release channels: cellular redox sensors? IUBMB Life 57 (2005) 315-322, https:// doi.org/10.1080/15216540500092328.

[84] G. Sánchez, Z. Pedrozo, R.J. Domenech, C. Hidalgo, P. Donoso, Tachycardia increases NADPH oxidase activity and RyR2 S-glutathionylation in ventricular muscle, J. Mol. Cell. Cardiol. 39 (2005) 982-991, https://doi.org/10.1016/ j.yjmcc.2005.08.010.

[85] R. Rizzuto, P. Bernardi, T. Pozzan, Mitochondria as all-round players of the calcium game, J. Physiol. 529 Pt 1 (2000) 37-47, https://doi.org/10.1111/ j.1469-7793.2000.00037.x.

[86] M.J. Bround, R. Wambolt, D.S. Luciani, J.E. Kulpa, B. Rodrigues, R.W. Brownsey, M.F. Allard, J.D. Johnson, Cardiomyocyte ATP production, metabolic flexibility, and survival require calcium flux through cardiac ryanodine receptors in vivo, J. Biol. Chem. 288 (2013) 18975-18986, https://doi.org/10.1074/ jbc.M112.427062.
[87] T. Tsuboi, G. da Silva Xavier, G.G. Holz, L.S. Jouaville, A.P. Thomas, G.A. Rutter, Glucagon-like peptide-1 mobilizes intracellular $\mathrm{Ca} 2+$ and stimulates mitochondrial ATP synthesis in pancreatic MIN6 beta-cells, Biochem. J. 369 (2003) 287-299, https://doi.org/10.1042/BJ20021288.

[88] G. Szabadkai, K. Bianchi, P. Várnai, D. De Stefani, M.R. Wieckowski, D. Cavagna, A.I. Nagy, T. Balla, R. Rizzuto, Chaperone-mediated coupling of endoplasmic reticulum and mitochondrial Ca2+ channels, J. Cell Biol. 175 (2006) 901-911, https://doi.org/10.1083/jcb.200608073.

[89] T.J. Collins, P. Lipp, M.J. Berridge, W. Li, M.D. Bootman, Inositol 1,4,5trisphosphate-induced $\mathrm{Ca} 2+$ release is inhibited by mitochondrial depolarization, Biochem. J. 347 (2000) 593-600, https://doi.org/10.1042/0264-6021: 3470593.

[90] G. Csordás, A.P. Thomas, G. Hajnóczky, Quasi-synaptic calcium signal transmission between endoplasmic reticulum and mitochondria, EMBO J. 18 (1999) 96-108, https://doi.org/10.1093/emboj/18.1.96.

[91] V.K. Sharma, V. Ramesh, C. Franzini-Armstrong, S.S. Sheu, Transport of Ca2+ from sarcoplasmic reticulum to mitochondria in rat ventricular myocytes, J. Bioenerg. Biomembr. 32 (2000) 97-104, https://doi.org/10.1023/A: 1005520714221.

[92] G. Hajnóczky, L.D. Robb-Gaspers, M.B. Seitz, A.P. Thomas, Decoding of cytosolic calcium oscillations in the mitochondria, Cell 82 (1995) 415-424, https://doi.org/10.1016/0092-8674(95)90430-1.

[93] C. Villalobos, L. Nuñez, M. Montero, A.G. García, M.T. Alonso, P. Chamero, J. Alvarez, J. García-Sancho, Redistribution of Ca2+ among cytosol and organella during stimulation of bovine chromaffin cells, Faseb. J. 16 (2002) 343-353, https://doi.org/10.1096/fj.01-0630com. 